\title{
Natural Radionuclides and Heavy Metals Concentration of Marine Sediments in Quseir City and Surrounding Areas, Red Sea Coast-Egypt
}

\author{
M. A. M. Uosif ${ }^{1 *}$, Madkour.Hashim ${ }^{2}$, Shams Issa ${ }^{1,3}$, Mahmoud Tamam $^{1}$ and \\ Hesham M. Zakaly ${ }^{1}$ \\ ${ }^{1}$ Faculty of Science, Al-Azhar University, Assuit branch, Egypt \\ ${ }^{2}$ National Institute of Oceanography and Fisheries, Red Sea Branch, Egypt \\ ${ }^{3}$ Faculty of Science, Tabok University, Tabok, Saud Arabia
}

\begin{abstract}
Concentrations of natural radionuclides ${ }^{226} \mathrm{Ra},{ }^{232} \mathrm{Th}$ and ${ }^{40} \mathrm{~K}$ as well as the radiological hazard parameters were calculated in the marine sediments in three regions in Quseir city along the Red Sea coast; El-Edua area, Phosphate Harbour and north Flaminko Village. The average activity concentrations of ${ }^{226} \mathrm{Ra},{ }^{232} \mathrm{Th}$ and ${ }^{40} \mathrm{~K}$ at El-Edua

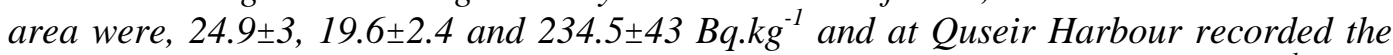
average activities concentrations were; $26.2 \pm 3.2,19.4 \pm 2.8$ and $458.6 \pm 164.2 \mathrm{~Bq} \cdot \mathrm{kg}^{-1}$ while at north Flaminko Village found to be; $25.7 \pm 6.9,22.6 \pm 5$ and $106.4 \pm 17.5 \mathrm{~Bq} . \mathrm{kg}^{-1}$ respectively in Quseir city, Egypt. Concentrations of the metals; $\mathrm{Mn}, \mathrm{Zn}, \mathrm{Cu}, \mathrm{Pb}, \mathrm{Ni}, \mathrm{Co}$ and $C d$ were determined by Atomic Absorption Spectrophotometry (AAS) using GBC$932 v e r .1 .1$ with detection limits of $0.01 \mathrm{ppm}$.
\end{abstract}

Keywords: radiation hazard; radionuclides; natural radioactivity; human health; regions; Red Sea; Egypt; marine sediments

\section{Introduction}

The Egyptian Red Sea coast is being stressed due to over exploitation and has become very vulnerable to human related activities. Generally, the main environmental problems and threats to the Red Sea ecosystem and geosystem include recreation and tourism activities, landfilling, dredging, oil pollution, water pollution, solid waste disposal, navigation activities, phosphate shipment pollution and fishing activities. As a result of the human activities, pollution extends along the shore, and is discharged to the nearshore waters. Some of these pollutants may directly or indirectly be captured by bottom sediments [1]. In the case of successive concentrations of these pollutants in bottom sediments, the later will act as a reservoir for pollutants. Therefore, studies of the recent sediments along the Red Sea coast are important in assessing potential environmental hazards resulting from the irrational human activities.

Marine sediments are the essential reservoir for natural and anthropogenic radionuclide retention because of their diverse composition. These sediments accumulate radionuclides as a result of scavenging and settling processes in the water column. The sediment movement and accumulation provide a strong signal about the sediment origin and future abnormality in the radionuclide concentrations. The natural radionuclides of the uranium and thorium series and ${ }^{40} \mathrm{~K}$ as well as the artificial radionuclides of ${ }^{137} \mathrm{Cs},{ }^{90} \mathrm{Sr}$ and ${ }^{239+240} \mathrm{Pu}$ are the major long-lived radionuclides already present or introduced into seas[2]. Among the former elements, the most abundant are ${ }^{40} \mathrm{~K}$ and the radioisotopes of the

* Corresponding author:

E-mail: Dr_Mohamed_Amin@Lycos.com (MAM Uosif)

Fax:+20882148095 
natural series of uranium, actinium and thorium including the parent nuclei ${ }^{235} \mathrm{U},{ }^{238} \mathrm{U}$ and ${ }^{232} \mathrm{Th}$ and the decay products from the successive alpha or beta decays, whereas the most abundant of the cosmogenic origin nuclei are ${ }^{14} \mathrm{C},{ }^{10} \mathrm{Be}$ and ${ }^{26} \mathrm{Al}[3]$.

Thorium isotopes have been widely used as tracers for particle dynamics in marine geochemistry. Particle-reactive radionuclides are useful as particle transport tracers. Particles of all sizes play a central role in the scavenging of particle-reactive radionuclides and pollutants in estuaries, coastal and open oceans [4,5] documented that the environmental radiotracers can be used to understand the underlying processes of the environment where they are found. The presence of artificial radionuclides in the marine environment can thus lead to radiation exposure through the ingestion of sea food [6] (Heldal et al., 2002).Investigators have reported a wide variation in the concentrations of uranium and radium in samples from various parts of the world. For uranium, a range from 3 to $400 \mathrm{ppm}$, corresponding to $37-4900 \mathrm{~Bq}^{238} \mathrm{U} \mathrm{kg}^{-1}\left(1 \mathrm{ppm} \mathrm{U}=12.23 \mathrm{~Bq}^{238} \mathrm{U} \mathrm{kg}^{-}\right.$ ${ }^{1}$ ) and for ${ }^{226} \mathrm{Ra}$, a range from 100 to $10000 \mathrm{~Bq} \mathrm{~kg}^{-1}$ is reported. It is within this context that the present study has been undertaken aimed at the determination of the radioactivity of naturally occurring nuclides in marine sediment. Also The present work aims to assess radiological hazards to the human health of the natural radionuclides $\left({ }^{226} \mathrm{Ra},{ }^{232} \mathrm{Th}\right.$ and ${ }^{40} \mathrm{~K}$ ) in three regions in Quseir city contain vary activation along the Red Sea; sewage and productions at El-Edua area and phosphate shipping activities at Phosphate Harbour and touristic activation in north city.

\section{Materials and Methods}

\subsection{Study Regions}

The study area divided into three areas, south (El-Edua area south Quseir), middle (Quseir Harbour) and north (north Flaminko village north Quseir city) (Figure 1).

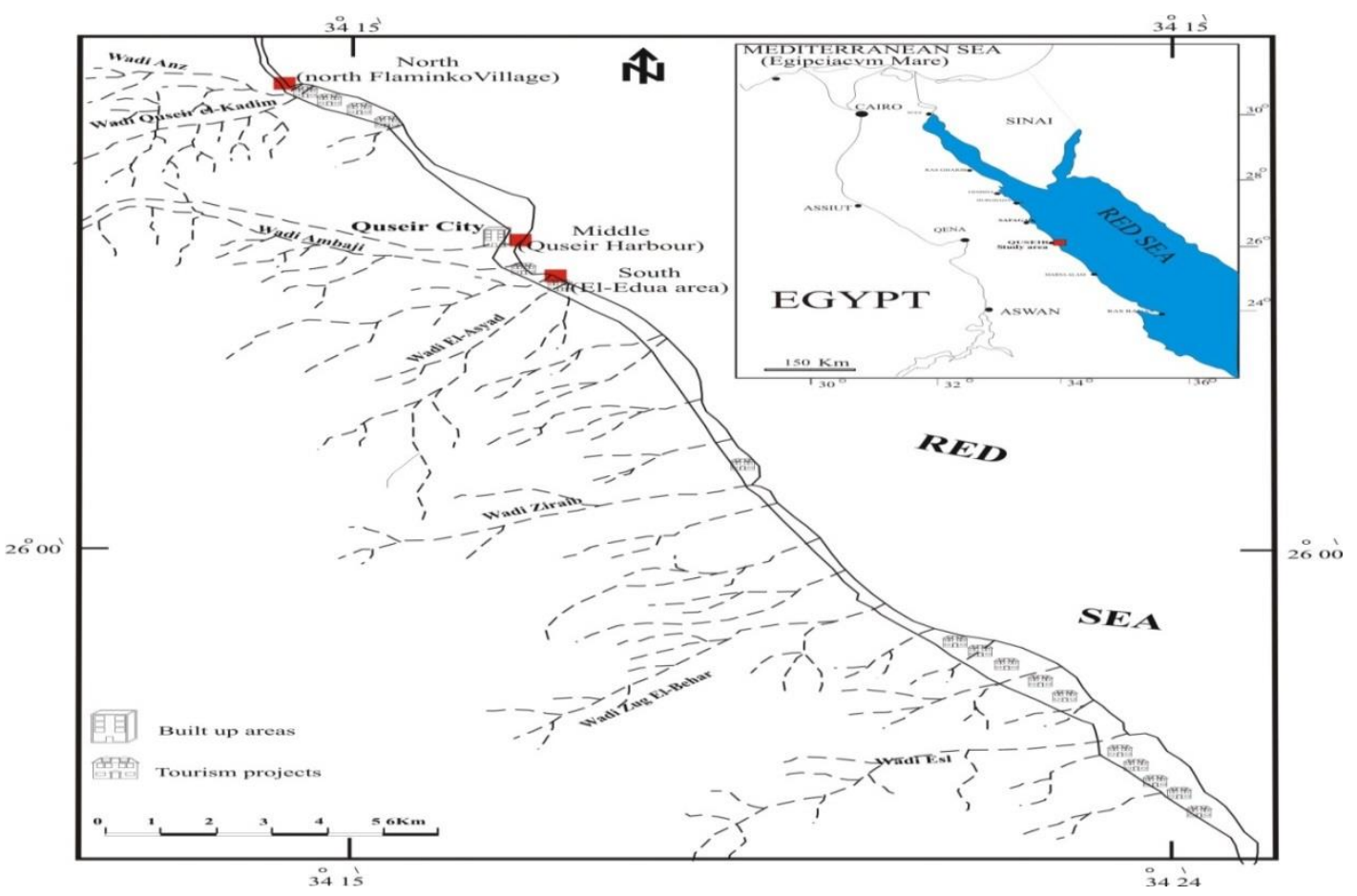

Figure 1. Map Showing the Drainage Network of Quseir Area, Location of Tourism Projects and the Three Areas were Studied at Quseir and Surrounding Areas 
1-El-Edua area is located south Quseir. The beach is $3 \mathrm{~m}$ wide, $30 \mathrm{~cm}$ high and sloping $8^{\circ}$ toward the Sea while the tidal flat is covered with sand, shell fragments, coral rubbles and scattered stones covering the bedrock. After $4.5 \mathrm{~cm}$ seaward from the shoreline a number of the Sea urchins appear. The needle-spine urchin was found in scattered aggregations on the reef flat around and in between cracks at $12.5 \mathrm{~m}$ from the shoreline. The presence of the different of Sea urchins continued all along the reef flat [7].

Quseir Harbour is located in Quseir City, and is considered from old Harbour on the Egyptian Red Sea coast. It is lying at latitudes $26^{\circ} 05^{`} 02^{\prime \prime} \mathrm{N}$ to $26^{\circ} 06^{\prime} 12^{\prime \prime} \mathrm{N}$ and longitudes $34^{\circ} 16^{\backslash} 58^{\prime \prime} \mathrm{E}$ to $34^{\circ} 17^{\prime} 08^{\prime \prime} \mathrm{E}$. This harbour lies in a small by at the mouth of Wadi Ambaji. The salinity of the water in Quseir Harbour is relatively high. It varies between $40.83 \%$ and $41.33 \%$ in spring season. The water temperatures in this season were $23.9^{\circ} \mathrm{C}$ and $24.89{ }^{\circ} \mathrm{C}$ terrigenous sediments have been transported to marine environment by Wadi Ambaji especially in the southern part of Quseir Harbour. It is observed that these sediments have a relatively large under cutting effect of the violent drive water during heavy torrents. The beach sediments are coarse sands. These sands are significant terrigenous fragments the tidal flat is very narrow and extends smoothly and slopes gently seaward. The sediments covering the bottom topography of this area are of fine sand to sandy mud. Most sediment samples have brown color. This is due to phosphate shipment operations. The system of the malaise of marine environment deterioration at Quseir area include the spread of algal blooms, dense seagrasses, coral bleaching and declining of productivity in addition to the poor biological activity of marine organisms especially coral reefs [2].

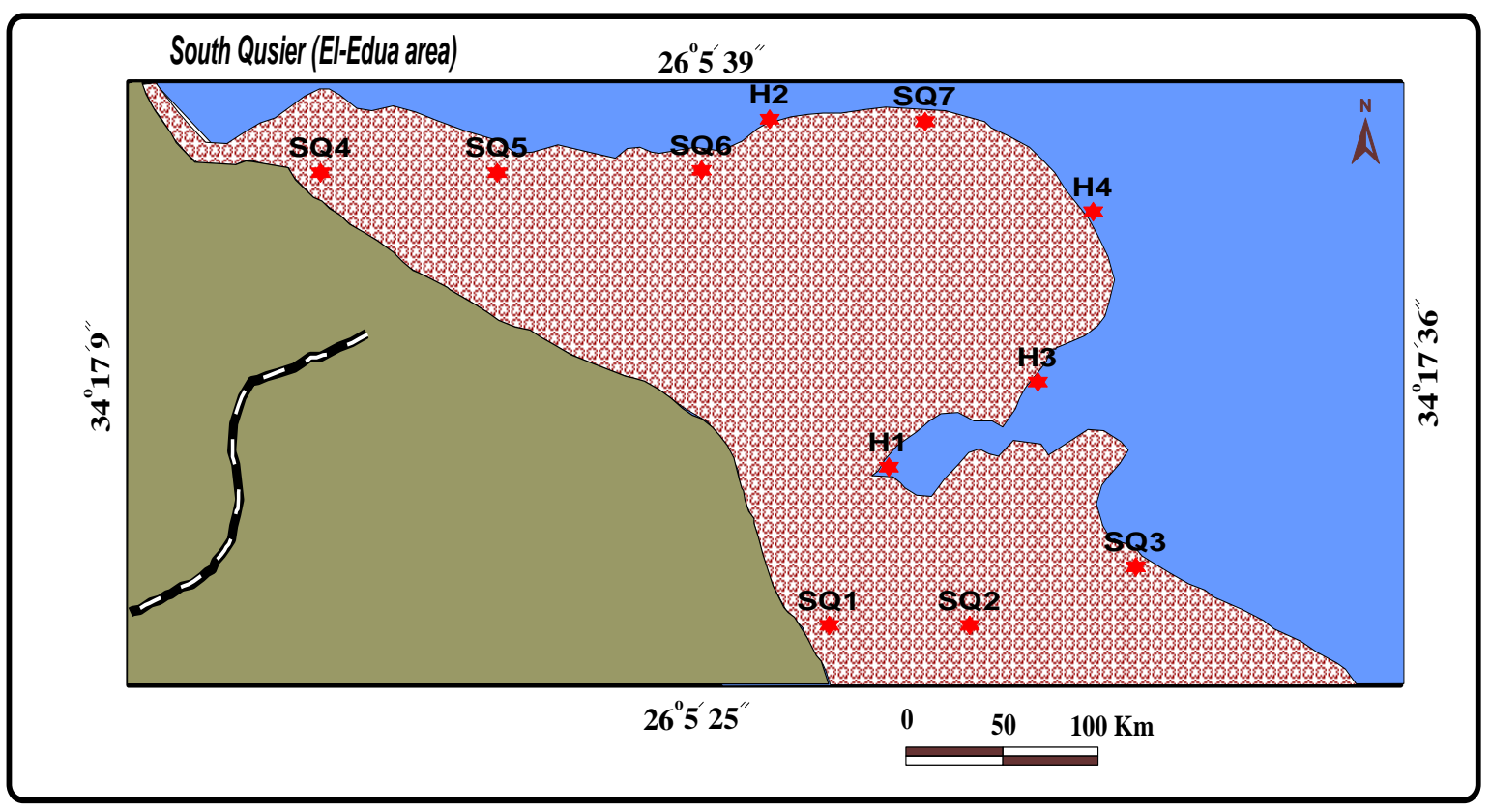



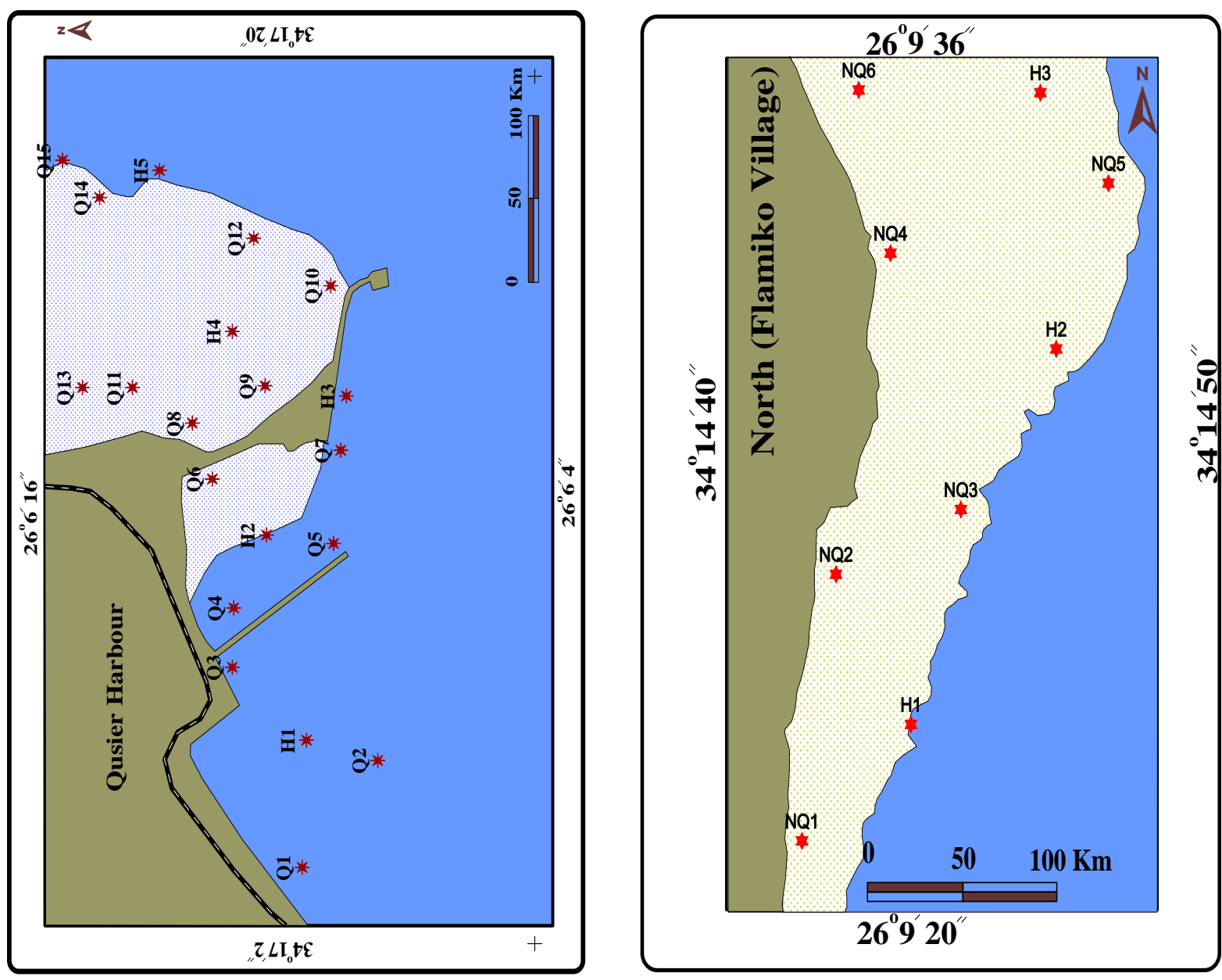

Figure 2. Samples Location in the Study Area

North Flaminko Village is located north Quseir City. The beach is $8 \mathrm{~m}$ wide, $50 \mathrm{~cm}$ high and sloping $12^{\circ}$ toward the Sea. The sandy substrate extends to $9 \mathrm{~m}$ where some scattered stones found. The presence of living coral colonies were in the form of separated smallbranched colonies of Acropora sp., Stylophora sp. at a depth of $45 \mathrm{~cm}$. The Sea urchin formed a dense population around the coral colonies and in between cracks on the reef flat at a depth of $60 \mathrm{~cm}, 23.7 \mathrm{~m}$ from the shoreline. The water depth increases as we go seaward to be $90 \mathrm{~cm}$ and at a distance of $59 \mathrm{~m}$, where coral flourished, either branched or massive forms, making a number of communities where coral reef fishes were so abundant. The algal community began to dominate at a distance of $89.5 \mathrm{~m}$ and a depth of $45 \mathrm{~cm}$. The dominant brown algal species forming dense long narrow mats of $2 \mathrm{~m}$ width covering the reef flat, $98 \mathrm{~m}$ from the shoreline at a depth of $60 \mathrm{~cm}$. Also the water depth decreased as we approached the reef slope where water movement was so strong and the reef flat was relatively bare at a depth of $10 \mathrm{~cm}$ and a distance $250 \mathrm{~m}$ from the shoreline. Reef slope is dominated by (Millepora sp.) according to Madkour and Ahmed (2006) [13].

\subsection{Sampling and Sample Preparation}

In this study, 28 sediment samples have been collected from the three selected localities: El-Edua area (South Quseir), Quseir Harbour (Middle area) and north Flaminko Village(North Quseir) (Figure 1). The location and description of bottom characteristics of the collected samples are given in (Figures 3). Surface sediment samples were collected by hand and scuba diving. Three different environmental zones such as (i) beach, (ii) 
intertidal zone and (iii) offshore zone until $8 \mathrm{~m}$ water depth represent these localities. Scuba diving was used in areas rich in corals where grab sampler failed to collect samples.

For gamma spectroscopic analysis, the samples were prepared as follows. Each sample (about $1 \mathrm{~kg}$ ) was washed in distilled water and dried at about $110^{\circ} \mathrm{C}$ to ensure that moisture is completely removed. The samples were crushed, homogenised and sieved through a 200 mesh, the optimum size to be enriched in heavy minerals. Weighted samples were placed in a polyethylene beaker of $350 \mathrm{~cm}^{3}$ volume. The beakers were completely sealed for 4 weeks to reach secular equilibrium where the rate of decay of the progency becomes equal to that of the parent (radium and thorium) [8;9]. This step is necessary to ensure that radon gas confined within the volume and the progeny will also remain in the sample.

Table 1. The Hydrographic Parameters of Water Mass in the Studied Areas

\begin{tabular}{cccccccc}
\hline $\begin{array}{c}\text { Studied } \\
\text { areas }\end{array}$ & $\begin{array}{c}\text { Depth } \\
(\mathrm{m})\end{array}$ & PH & Sal $\%$ & $\begin{array}{c}\text { Temp. } \\
\left({ }^{\circ} \mathrm{C}\right)\end{array}$ & $\begin{array}{c}\text { TDS } \\
(\mathrm{ppt})\end{array}$ & $\begin{array}{c}\text { sea water } \\
\text { spec.grav } \\
(\sigma \mathrm{t})\end{array}$ & $\begin{array}{c}\text { Conductivity } \\
(\mathrm{ms} / \mathrm{cm})\end{array}$ \\
\hline & 1 & 8.75 & 42.28 & 21.94 & 31.31 & 29.8 & 62.63 \\
South (El- & 1.5 & 8.63 & 42.28 & 22.11 & 31.25 & 29.7 & 62.51 \\
Edua area) & 2 & 8.76 & 42.07 & 21.94 & 31.18 & 29.6 & 62.35 \\
& 8 & 8.73 & 42.56 & 20.62 & 31.49 & 30.4 & 62.98 \\
& 1 & 8.76 & 42.51 & 23.7 & 31.49 & 29.4 & 62.97 \\
Middle & 1 & 8.65 & 42.45 & 21.72 & 31.42 & 30 & 62.84 \\
(Quseir & 3 & 8.6 & 42.24 & 22.24 & 31.29 & 29.7 & 62.58 \\
Harbour) & 0.3 & 9.12 & 43.08 & 23.33 & 31.85 & 30 & 63.7 \\
& 0.5 & 8.82 & 42.41 & 22.04 & 31.4 & 29.9 & 62.8 \\
& 0.5 & 8.93 & 43.35 & 22.2 & 32.01 & 30.5 & 64.02 \\
North (north & 0.5 & 8.88 & 42.64 & 23.17 & 31.56 & 29.7 & 63.12 \\
Flaminko & 0.5 & 9.48 & 43.28 & 22.48 & 31.97 & 30.4 & 63.94 \\
Village) & & & & & &
\end{tabular}

Note: All parameters were measured during collecting samples by Hydrolab Instrument

\subsection{Instrumentation and Calibration}

Global Positioning System (GPS; Magellan) for the determination of the coordinates. The temperature, salinity, $\mathrm{pH}$, total dissolved salts (TDS) and specific electrical conductivity (SEC) were measured at different depths using the Hydrolab Instrument (Surveyor4, 1997) during sample collection at the studied localities (Table 1). Grain size analysis providing basic information for the geochemical investigations of marine sediments was carried out by mechanical wet sieving. Geochemical analysis was carried out on all sediment samples including the determination of total carbonate (TC) content, the determination of total organic matter (TOM) by sequential weight loss at $550 \circ \mathrm{C}[10$, 11, 12] (Dean Jr EW, 1974; Flannery et al., 1982; Brenner and Binford, 1988). Concentrations of the metals; $\mathrm{Mn}, \mathrm{Zn}, \mathrm{Cu}, \mathrm{Pb}, \mathrm{Ni}, \mathrm{Co}$ and $\mathrm{Cd}$ were determined according to Chester et al., (1994) [13] (Chester et al., 1994). 0.5 gram of the prepared ground sample was completely digested in a Teflon cup by using a mixture of conc. Nitric 
(HNO3), per chloric (HClO4) and hydrofluoric acids (HF) in the ratio 3:2:1, respectively. Acids were slowly added to the dried sample and left over night before heating. Samples were heated at a temperature of approximately $200{ }^{\circ} \mathrm{C}$, then left to cool and filtered to get rid of the non-digested parts. The solution was justified to a volume of $25 \mathrm{ml}$ and the concentration of elements were determined by Atomic Absorption Spectrophotometry (AAS) using GBC-932ver.1.1 with detection limits of $0.01 \mathrm{ppm}$ (National Institute of Oceanography and Fisheries, Red Sea Branch).Results were expressed in $\left(\mu \mathrm{g} \mathrm{g}^{-1}\right)$.

Activity measurements were performed by $\gamma$-ray spectrometry, employing a $3^{\prime \prime} \times 3^{\prime \prime}$ scintillation $\mathrm{NaI}(\mathrm{Tl})$ detector. The hermetically sealed assembly is coupled to a personal computer-multichannel analyzer (Canberra AccuSpec). A dedicated software program (Genie 2000) analysed each measured $\gamma$-ray spectrum. To reduce $\gamma$-ray background, a cylindrical lead shield (100mm thick) with a fixed bottom and movable cover shielded the detector. The lead shield contained an inner concentric cylinder of copper $(0.3 \mathrm{~mm}$ thick) to absorb lead X-rays. In order to determine the background distribution in the environment around the detector, an empty sealed beaker was counted in the same manner and in the same geometry as the samples. The efficiency calibration curve was made using Reference Materials (IAEEA-314) international Atomic Energy Agency which have known activity of ${ }^{226} \mathrm{Ra}\left(732 \mathrm{~Bq} \cdot \mathrm{kg}^{-1}\right)$ and ${ }^{232} \mathrm{Th}\left(72 \mathrm{~Bq} \cdot \mathrm{kg}^{-1}\right)$.

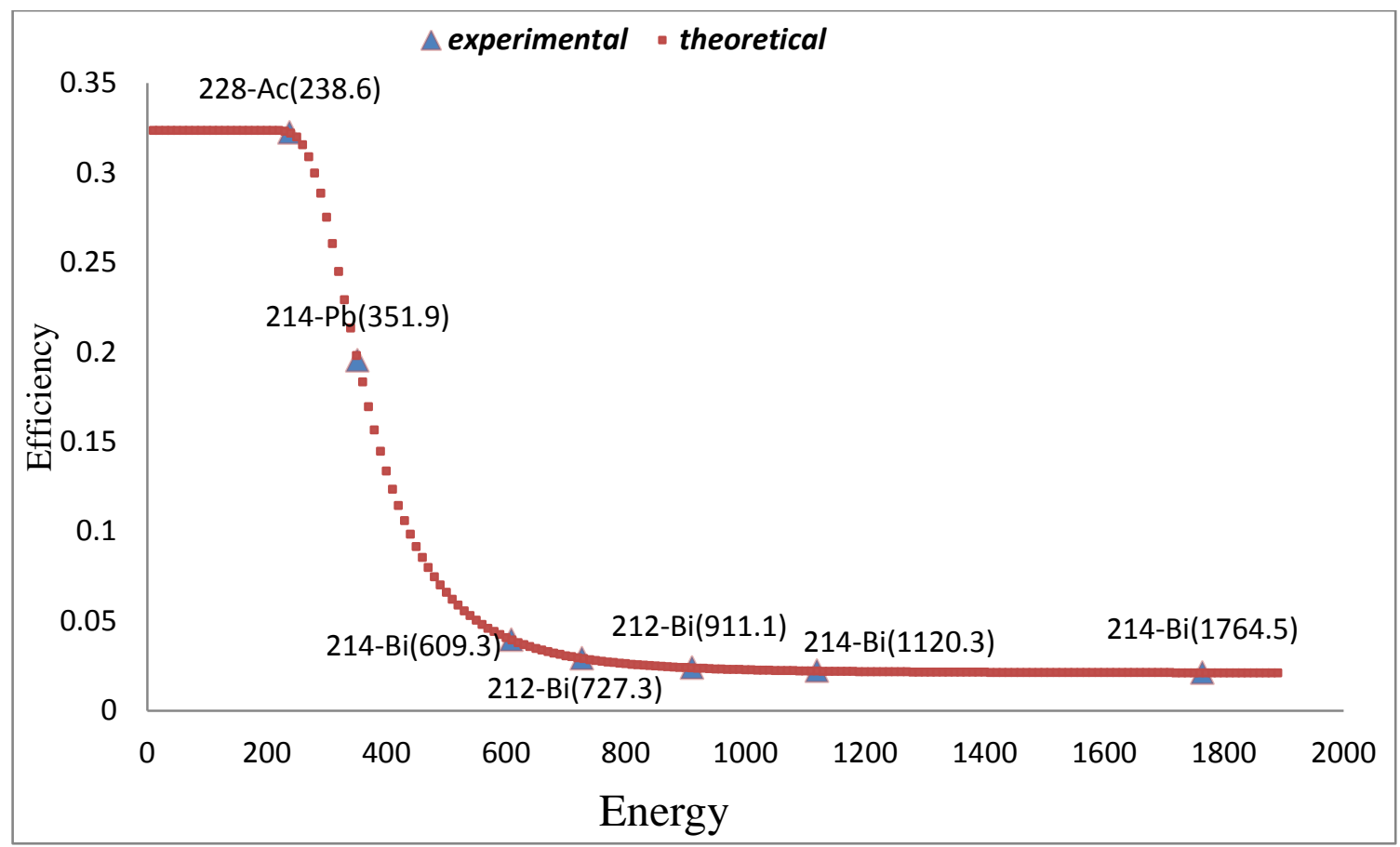

\section{Results and Discussion}

\subsection{Environmental Conditions}

Oceanographic conditions prevailing along the shore have an exchangeable influence on the coastal features. The oceanographic parameters affect the shore environment and simultaneously have an impact on the shore activities. Most oceanographic parameters were measured at the study areas (Table 1). The salinity of seawater in Quseir harbour is high and varies between $42.24 \%$ at depth $3 \mathrm{~m}$ and $43.08 \%$ at depth $0.3 \mathrm{~m}$. The water temperature ranges between $21.72{ }^{\circ} \mathrm{C}$ at depth $1 \mathrm{~m}$ and $23.7^{\circ} \mathrm{C}$ at depth $1 \mathrm{~m}$ in the winter season (Table 1). The salinity of seawater in north Flaminko Village ranges between $42.64 \%$ at depth $0.5 \mathrm{~m}$ and $43.35 \%$ at depth $0.5 \mathrm{~m}$, and the water temperatures are between $22.2^{\circ} \mathrm{C}$ at depth $0.5 \mathrm{~m}$ and $23.17^{\circ} \mathrm{C}$ at depth $0.5 \mathrm{~m}$ in the winter season (Table 1). The 
salinity of the water in El-Edua area is high and varies between $42.07 \%$ at depth $2 \mathrm{~m}$ and $42.56 \%$ at depth $8 \mathrm{~m}$, while the water temperatures are between $20.62{ }^{\circ} \mathrm{C}$ at depth $8 \mathrm{~m}$ and $22.11{ }^{\circ} \mathrm{C}$ at depth $1.5 \mathrm{~m}$ in the winter season (Table 1 ).

\subsection{Sediment Texture}

The purpose of the mechanical analysis for sediments is not only to obtain the nature of sediments but also to understand the physical characteristics of these sediments and to reveal the relation and the influence of grain size, source material and depositional environment. The areas under study receive sediments from two different sources; the terrigenous rock fragments from the hinter land mountains and skeletal carbonates from the sea (i.e., siliclastic and carbonate sediments, respectively). In these mixed environments, the terrigenous components are introduced from outside the depositional basin, whereas the skeletal carbonates originates mainly from near the depositional basin [14] (Mansour, 1995). The skeletal carbonates have a remarkably limited history of transportation and deposition. However, it is not easy to reveal the hydrodynamic behavior of the skeletal fragments, which is dependent on shape, density and size $[15,16]$ (Maiklem,1968; Braithwaite, 1973) Generally, the particle size of the sediments changes from coarse sand near the beach to fine sand with increasing distance from the beach towards the deeper water.

Sediments of the investigated beach and intertidal bottoms facies are composed of over 83\% sand Figure (4) Table (2). Very fine sand, five sand and medium sand are the most dominant the beach sediments, whereas coarse sand and very coarse sand are the most abundant fractions in the intertidal sediment Figure (4). Gravel is common in the intertidal samples and reach up to $31 \%$ with an average of $6 \%$ especially in El-Edua area and north Flaminko Village. Mud is relatively higher in the beach samples than in the intertidal sediments at quseir Harbour. The areal distribution of sediments and the variation of their grain characteristic are controlled to a great extent by the nature of the coastal sediments, bottom facies and hydrodynamic status along the coast [17].

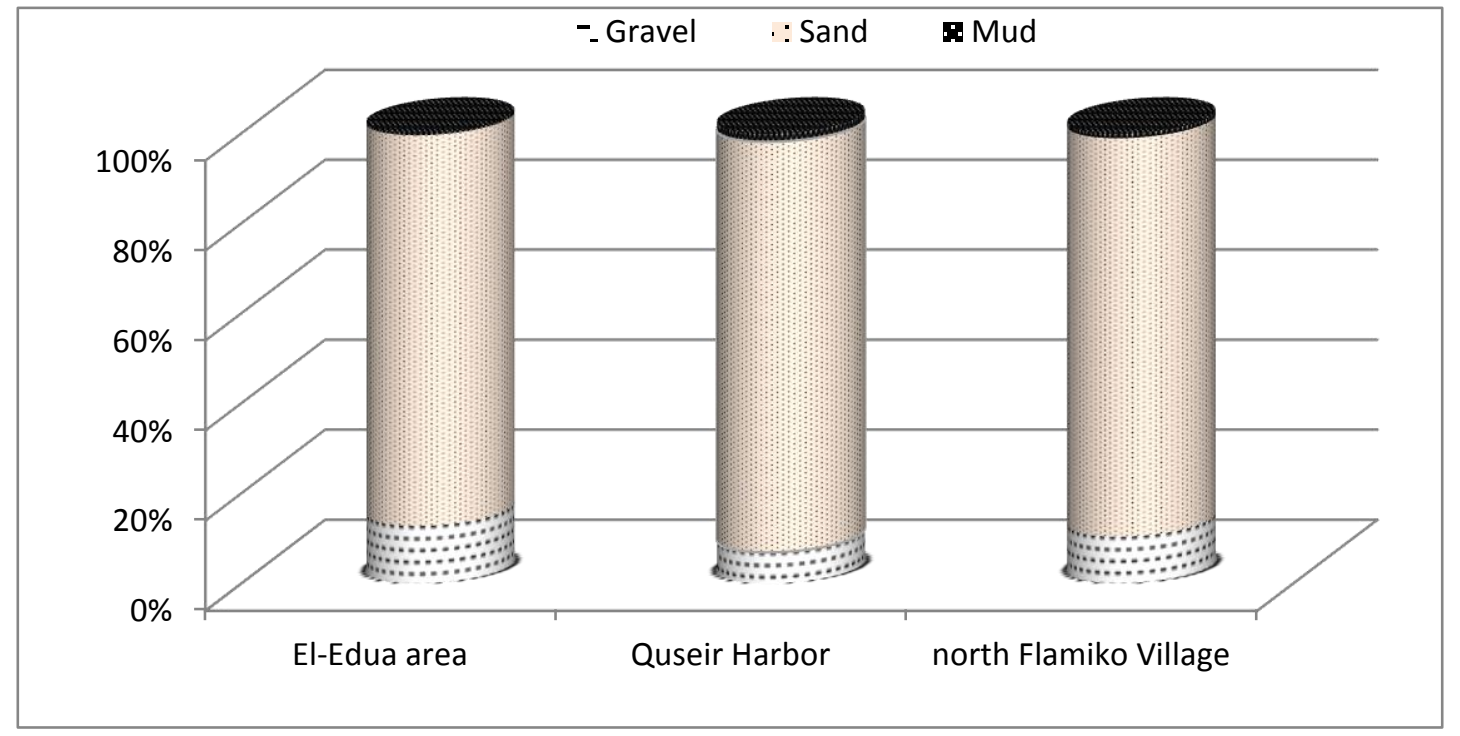

Figure 4. Distribution of Gravel, Sand and Mud Fractions of the Sediment Samples at the Studied Regions 


\subsection{Geochemistry}

\subsubsection{Carbonates}

The average carbonates content in the studied sediments varies from $30.02 \%$ at ElEdua area to $76.16 \%$ at north Flminko Village (Table 2, Figure 5). Noth Flaminko Village area recorded the highest values of corbonate contents compared with the studied areas. It is due to terrestrial materials from erosion boundary limestone rock and biogenic from accumulation of skeletal grains. Similar observation was also recorded in the shallow carbonate sediments of Hurghada and El Esh area [2].

On other hand, The principal sources of carbonate in marine sediment are: 1) Inorganic chemical precipitation. 2) Residual from weathering of limestone rock on the sea floor. 3) Terrestrial rock. and 4) Biogenic from accumulation of skeletal grains.

\subsubsection{Total Organic Matter}

Organic matter affects the aquatic ecosystem by interacting with in organic matter to form complex compounds, which include in its structure several other elements. It also serves as a source of food for several animal groups. In general, the beach sediments of this area have values of organic carbon that range from $0.32 \%$ to $1.67 \%$ and total organic matter content which varies from $0.58 \%$ to $30 \%$. The content of organic matter in intertidal sediment varies from $6.84 \%$ at north Flaminko Village area to $24.08 \%$ at Quseir Harbour (Table 2; Figure 5). Quseir Harbour and El-Edua area recorded the highest values of organic matter content compared with north Flaminko Village area. The aerial distribution of the organic matter shown a general decrease toward the north. [18] attributed the high content of the organic matter in tidal flat sediments to the terrigenous flux. Also, they recorded that the terrestrial materials rich in organic matter and the high organic productivity are the two main reasons for the higher organic matter content.

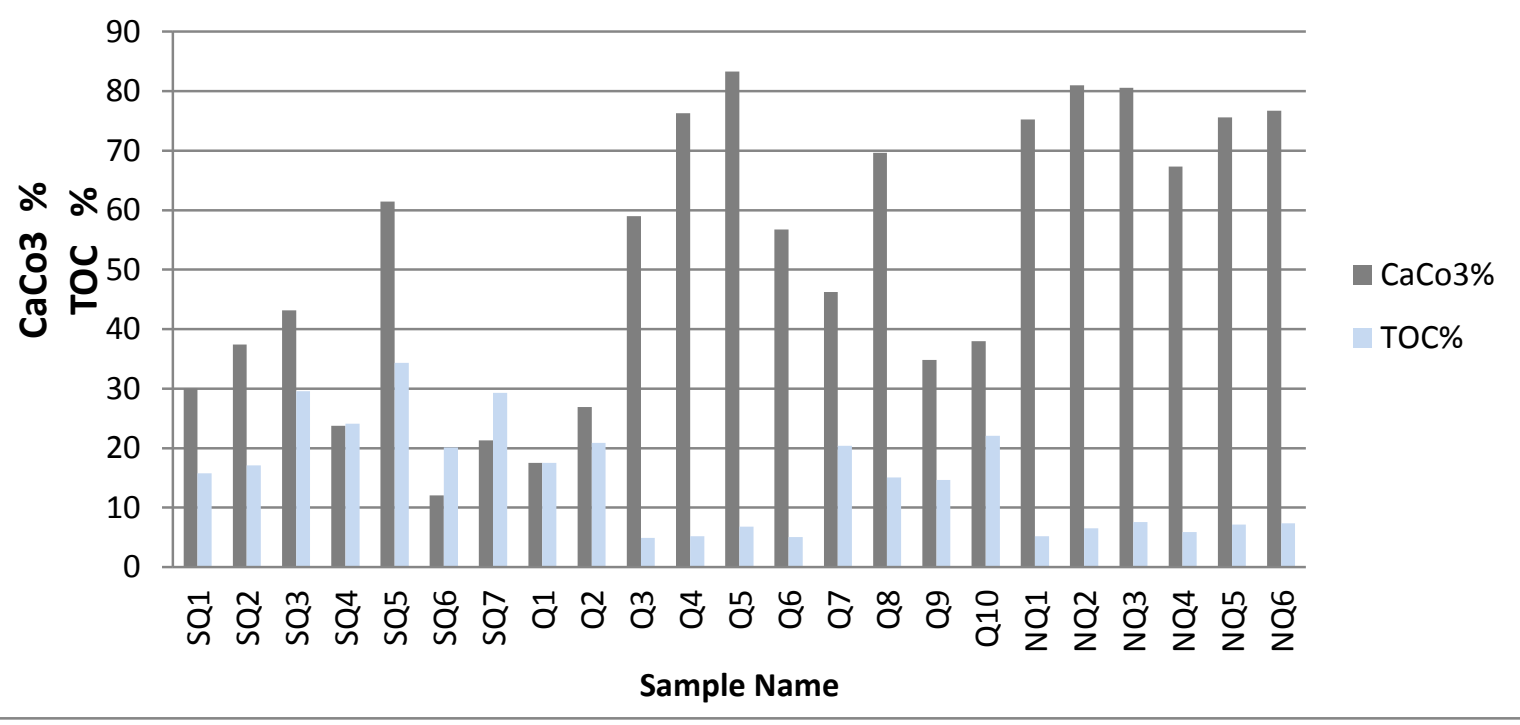

Figure 5. Distribution of Carbonate Content, Total Organic Matter of Marine Sediments of Quseir City 
Table 2. Sediment Types, Geochemical Properties, heavy metals and water Depth of Sediment Samples at the Study Areas

\begin{tabular}{|c|c|c|c|c|c|c|}
\hline \multirow[b]{2}{*}{ Variables } & \multicolumn{2}{|c|}{$\begin{array}{l}\text { South (El-Edua area) } \\
\qquad(n=7)\end{array}$} & \multicolumn{2}{|c|}{$\begin{array}{c}\text { Middle (Quseir harbour) (n } \\
=10 \text { ) }\end{array}$} & \multicolumn{2}{|c|}{$\begin{array}{l}\text { North (north Flaminko Village) } \\
\qquad(n=6)\end{array}$} \\
\hline & Range (\%) & Mean (\%) & Range (\%) & Mean (\%) & Range (\%) & Mean (\%) \\
\hline Gravel & $0.5-32$ & 9.3 & $0.0-31.1$ & 2.7 & $0.2-31.1$ & 6.9 \\
\hline Sand & $68-99.1$ & 89.4 & $68.8-97.3$ & 94.9 & $68.8-97$ & 92.7 \\
\hline Mud & $0.0-1.5$ & 0.3 & $0.1-8.5$ & 1.2 & $0.0-2.8$ & 0.8 \\
\hline Carb.\% & $12.1-61.5$ & 30.0 & $17-83.3$ & 51.5 & $67.4-81$ & 76.2 \\
\hline TOM\% & $15.8-34.4$ & 24.1 & $4.9-22$ & 14.9 & $5.2-7.5$ & 6.8 \\
\hline $\mathrm{Fe}^{*}$ & 4987-8927 & 6930.0 & 9500-16000 & 11321.5 & $3245-6543$ & 4932.0 \\
\hline$M n^{*}$ & $187.7-390$ & 249.6 & 500-1000 & 727.4 & $98.9-456.6$ & 220.2 \\
\hline $\mathrm{Zn}^{*}$ & 11.7-32 & 17.9 & 37.8-110 & 87.4 & 7.9-23 & 14.9 \\
\hline $\mathrm{Cu}^{*}$ & $3.5-10.7$ & 9.9 & $19-60$ & 33.3 & $3.5-15.5$ & 9.4 \\
\hline $\mathrm{Pb}^{*}$ & $1.5-8.1$ & 3.9 & 23.9-75 & 45.4 & $5.7-18$ & 10.9 \\
\hline $\mathrm{Ni}^{*}$ & $5.3-16.2$ & 13.1 & $24.6-65$ & 55.7 & $4.5-25.5$ & 12.8 \\
\hline Co* & $2.8-5.5$ & 4.4 & $2.8-11.7$ & 10.9 & $1.6-5$ & 3.8 \\
\hline $\mathrm{Cd}^{*}$ & $0.09-0.03$ & 0.2 & $0.97-3.1$ & 2.0 & $0.09-0.6$ & 0.4 \\
\hline Depth (m) & $0.3-3.0$ & 1.0 & $1.0-8.0$ & 1.8 & $0.0-0.5$ & 0.5 \\
\hline
\end{tabular}

Notes: $\mathrm{n}$, number of samples; *Values in $\mu \mathrm{g} \mathrm{g}^{-1}$

Table 3. Correlation Coefficients between Grain Size Analysis, Heavy Metals and Geochemical Analyses in Marine Sediments at the Study Areas

\begin{tabular}{|c|c|c|c|c|c|c|c|c|c|c|c|c|c|c|}
\hline & Gravel & Sand & Mud & $\mathrm{Fe}^{*}$ & $M n^{*}$ & $Z n^{*}$ & $\mathrm{Cu} *$ & $P b^{*}$ & $\mathrm{Ni}^{*}$ & $\mathrm{Co}^{*}$ & $C d^{*}$ & Carb.\% & OC\% & TOM\% \\
\hline \multicolumn{4}{|c|}{ south (EI-Edua area) } & & & & & & & & & & & \\
\hline Gravel & 1 & & & & & & & & & & & & & \\
\hline Sand & -1.00 & 1 & & & & & & & & & & & & \\
\hline Mud & -0.51 & 0.47 & 1 & & & & & & & & & & & \\
\hline $\mathrm{Fe}^{*}$ & 0.36 & -0.33 & -0.72 & 1 & & & & & & & & & & \\
\hline$M n^{*}$ & -0.10 & 0.11 & -0.13 & 0.57 & 1 & & & & & & & & & \\
\hline $\mathrm{Zn} *$ & -0.21 & 0.22 & -0.03 & 0.61 & 0.58 & 1 & & & & & & & & \\
\hline $\mathrm{Cu}^{*}$ & 0.36 & -0.33 & -0.72 & 1 & 0.57 & 0.61 & 1 & & & & & & & \\
\hline $\mathrm{Pb}^{*}$ & -0.07 & 0.10 & -0.56 & 0.51 & 0.57 & -0.02 & 0.51 & 1 & & & & & & \\
\hline $\mathrm{Ni*}$ & -0.19 & 0.18 & 0.17 & 0.37 & 0.19 & 0.90 & 0.37 & -0.39 & 1 & & & & & \\
\hline Co* & 0.47 & -0.45 & -0.59 & 0.92 & 0.54 & 0.43 & 0.92 & 0.57 & 0.22 & 1 & & & & \\
\hline $\mathrm{Cd}^{*}$ & 0.30 & -0.35 & 0.69 & -0.22 & 0.12 & 0.11 & -0.22 & -0.50 & 0.23 & -0.03 & 1 & & & \\
\hline Carb.\% & -0.15 & 0.12 & 0.77 & -0.56 & 0.15 & -0.19 & -0.56 & -0.38 & -0.17 & -0.45 & 0.78 & 1 & & \\
\hline OC\% & -0.01 & -0.01 & 0.36 & -0.82 & -0.15 & -0.69 & -0.82 & -0.07 & -0.70 & -0.71 & 0.18 & 0.53 & 1 & \\
\hline TOM\% & -0.01 & -0.01 & 0.36 & -0.82 & -0.15 & -0.69 & -0.82 & -0.07 & -0.70 & -0.71 & 0.18 & 0.53 & 1 & 1 \\
\hline
\end{tabular}

Middle (Quseir Harbour)

$\begin{array}{lrl}\text { Gravel } & 1 & \\ \text { Sand } & -0.97 & 1\end{array}$




\begin{tabular}{lrrrrrrrrrrrrrr} 
Mud & -0.46 & 0.23 & 1 & & & & & & & & & & \\
Fe* & 0.92 & -0.85 & -0.78 & 1 & & & & & & & & & \\
Mn* & 0.82 & -0.90 & -0.37 & 0.55 & 1 & & & & & & & \\
Zn* & 0.96 & -0.88 & -0.82 & 0.80 & 0.84 & 1 & & & & & & & \\
Cu$^{*}$ & 0.46 & -0.34 & -0.60 & 1 & -0.10 & 0.29 & 1 & & & & & & \\
$\mathrm{~Pb}^{*}$ & 0.82 & -0.83 & -0.52 & 0.94 & 0.51 & 0.62 & 0.76 & 1 & & & & & \\
$\mathrm{Ni}^{*}$ & 0.84 & -0.66 & -0.98 & 0.88 & 0.44 & 0.86 & 0.67 & 0.67 & 1 & & & & \\
Co* & 0.80 & -0.76 & -0.62 & 0.50 & 0.89 & 0.92 & -0.11 & 0.32 & 0.63 & 1 & & & \\
Cd* & 0.95 & -0.85 & -0.87 & 0.98 & 0.61 & 0.89 & 0.69 & 0.86 & 0.95 & 0.64 & 1 & & \\
Carb.\% & 0.56 & -0.48 & -0.45 & 0.70 & 0.80 & 0.99 & 0.20 & 0.49 & 0.84 & 0.95 & 0.83 & 1 & \\
OC\% & -0.23 & 0.17 & 0.29 & -0.73 & -0.97 & -0.91 & -0.14 & -0.68 & -0.61 & -0.87 & -0.78 & -0.71 & 1 \\
TOM\% & -0.23 & 0.17 & 0.29 & -0.73 & -0.97 & -0.91 & -0.14 & -0.68 & -0.61 & -0.87 & -0.78 & -0.71 & 1 \\
\hline
\end{tabular}

\section{north (north Flaminko Village)}

\begin{tabular}{|c|c|c|c|c|c|c|c|c|c|c|c|c|c|c|}
\hline Gravel & 1 & & & & & & & & & & & & & \\
\hline Sand & -1.00 & 1 & & & & & & & & & & & & \\
\hline Mud & -0.72 & 0.67 & 1 & & & & & & & & & & & \\
\hline $\mathrm{Fe}^{*}$ & 0.46 & -0.44 & -0.52 & 1 & & & & & & & & & & \\
\hline $\mathrm{Mn} *$ & -0.18 & 0.14 & 0.48 & -0.53 & 1 & & & & & & & & & \\
\hline $\mathrm{Zn} *$ & -0.17 & 0.22 & -0.29 & -0.50 & -0.03 & 1 & & & & & & & & \\
\hline $\mathrm{Cu}^{*}$ & -0.52 & 0.50 & 0.58 & -1 & 0.62 & 0.52 & 1 & & & & & & & \\
\hline $\mathrm{Pb}^{*}$ & -0.17 & 0.20 & -0.17 & -0.29 & 0.28 & 0.79 & 0.49 & 1 & & & & & & \\
\hline $\mathrm{Ni}^{*}$ & -0.16 & 0.17 & 0.04 & -0.71 & 0.56 & 0.79 & 0.81 & 0.84 & 1 & & & & & \\
\hline Co* & -0.55 & 0.56 & 0.30 & -0.45 & 0.67 & 0.48 & 0.64 & 0.78 & 0.74 & 1 & & & & \\
\hline $\mathrm{Cd}^{*}$ & -0.52 & 0.51 & 0.42 & -0.42 & 0.30 & 0.47 & 0.66 & 0.75 & 0.64 & 0.70 & 1 & & & \\
\hline Carb.\% & -0.68 & 0.68 & 0.48 & -0.77 & 0.20 & 0.67 & 0.86 & 0.59 & 0.69 & 0.58 & 0.82 & 1 & & \\
\hline OC\% & -0.61 & 0.57 & 0.85 & -0.56 & 0.08 & -0.19 & 0.49 & -0.39 & -0.11 & -0.09 & 0.21 & 0.50 & 1 & \\
\hline TOM\% & -0.61 & 0.57 & 0.85 & -0.56 & 0.08 & -0.19 & 0.49 & -0.39 & -0.11 & -0.09 & 0.21 & 0.50 & 1 & 1 \\
\hline
\end{tabular}

*Values in $\mu \mathrm{g} \mathrm{g}^{-1}$

\subsection{Heavy Metals Distribution}

In the present work, marine sediments from El-Edua area, Quseir Harbour and north Flaminko village were analyzed to detect the concentration and distribution of eight metals ( $\mathrm{Fe}, \mathrm{Mn}, \mathrm{Ni}, \mathrm{Co}, \mathrm{Zn}, \mathrm{Cu}, \mathrm{Pb}$ and $\mathrm{Cd}$ ) in order to understand the effect of human action and natural unputs on the quality of marine sediments, (Table 4).

The eight heavy metals ( $\mathrm{Fe}, \mathrm{Mn}, \mathrm{Zn}, \mathrm{Cu}, \mathrm{Pb}, \mathrm{Ni}, \mathrm{Co}$ and $\mathrm{Cd}$ ) showed a wide range of concentrations. Fe concentration of marine sediments varies between $3245 \mu \mathrm{g} \mathrm{g}^{-1}$ at north area (north Flaminko area) and $16000 \mu \mathrm{g} \mathrm{g}^{-1}$ at the middle area (Quseir Harbour). In the same manner Mn level ranges from $98.98 \mu \mathrm{g} \mathrm{g}^{-1}$ at north Flminko Village area to $1000 \mu \mathrm{g}$ $\mathrm{g}^{-1}$ at Quseir Harbour. The association of iron and manganese is well known; [19] reported that in the igneous silicate rocks, $\mathrm{Mn}$ is present in divalent state associated with ferromagnesium and accessory iron minerals. There are many sources for iron and manganese transfer to the marine environment. In the present work Fe and Mn transfer to the marine environment naturally by Wadis [20]. Quseir Harbour recorded the highest values compared with the other studied area due to shipment of mineral products from phosphate mines in the Eastern Desert in the past time. 
Obviously, the concentration of heavy metals $(\mathrm{Zn}, \mathrm{Cu}, \mathrm{Pb}, \mathrm{Co}$ and $\mathrm{Cd})$ recoded high values in Quseir Harbour compared with the south area (Ed Edua area) and the north area (north Flaminko Village area).

The relationships showed that Fe and $\mathrm{Mn}$ are negatively correlated with carbonate, depth and distance from the shoreline and positively correlated with zinc, nickel, cobalt, phosphorus and mean size (Table 3). A number of anthropogenic activities in Quseir Harbour are the main reasonable sources for the high heavy metals contents.

Results of correlation coefficients of carbonate and total organic matter with heavy metals show positive correlations and negative correlations at the areas under study (Table 3).

From the Permissible Levels of heavy metals ( $\mu \mathrm{g}$ g-1) for marine Sediments Quality Guidelines according to Canadian, Ontario and Florida Guidelines (Table 5)(Bennet and Cubbage, 1991; Persaud et al., 1990; MacDonald et al., 1996) we found $\mathrm{Cu}, \mathrm{Cd}$ and $\mathrm{Ni}$ are reach The Probable Effect Level (PEL) in Quseir Harbour, while in the residual station in The Threshold Effect Level (TEL).

Table 4. Heavy Metals Distribution of Marine Sediments at Quseir City

\begin{tabular}{|c|c|c|c|c|c|c|c|c|c|}
\hline & $\begin{array}{c}\text { Sample } \\
\text { name }\end{array}$ & $\mathrm{Cu}$ & $\mathrm{Zn}$ & $\mathrm{Pb}$ & $\mathrm{Cd}$ & $\mathrm{Fe}$ & $\mathrm{Mn}$ & $\mathrm{Ni}$ & Co \\
\hline \multirow{6}{*}{ 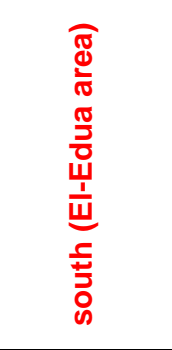 } & SQ1 & 13.0 & 20.0 & 4.5 & 0.3 & 7125 & 274.5 & 16.3 & 5.5 \\
\hline & SQ2 & 10.8 & 32.0 & 2.8 & 0.3 & 8925 & 337.5 & 32.5 & 4.3 \\
\hline & SQ3 & 10.3 & 18.0 & 8.1 & 0.2 & 5310 & 390.0 & 5.4 & 4.5 \\
\hline & SQ4 & 8.3 & 15.7 & 3.2 & 0.1 & 6735 & 187.8 & 11.5 & 3.3 \\
\hline & SQ5 & 3.6 & 11.8 & 1.6 & 0.3 & 4987 & 193.8 & 9.7 & 2.9 \\
\hline & SQ6 & 9.5 & 17.9 & 6.2 & 0.1 & 8346 & 224.7 & 14.7 & 4.5 \\
\hline \multirow{6}{*}{ 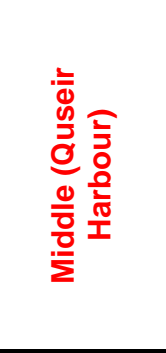 } & Q2 & 19.8 & 37.9 & 40.8 & 1.0 & 9876 & 600.3 & 24.7 & 9.4 \\
\hline & Q4 & 45.0 & 110.0 & 75.0 & 2.2 & 16000 & 1000.0 & 65.0 & 12.0 \\
\hline & Q7 & 60.0 & 65.0 & 60.0 & 1.8 & 14000 & 500.0 & 60.0 & 9.5 \\
\hline & Q8 & 23.6 & 88.4 & 39.8 & 1.6 & 11867 & 754.8 & 56.7 & 11.8 \\
\hline & Q12 & 35.0 & 90.0 & 50.0 & 2.5 & 9500 & 700.0 & 45.0 & 11.5 \\
\hline & Q14 & 31.7 & 86.4 & 23.9 & 3.1 & 10776 & 865.5 & 54.7 & 10.3 \\
\hline \multirow{6}{*}{ 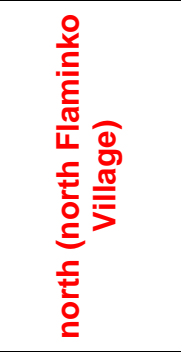 } & NQ1 & 7.5 & 19.0 & 18.0 & 0.5 & 5950 & 240.0 & 16.0 & 5.0 \\
\hline & NQ2 & 15.5 & 23.5 & 17.0 & 0.5 & 3245 & 308.0 & 25.5 & 4.1 \\
\hline & NQ3 & 11.0 & 14.0 & 12.3 & 0.6 & 5000 & 180.0 & 11.0 & 3.5 \\
\hline & NQ4 & 3.5 & 8.0 & 5.8 & 0.1 & 6543 & 200.5 & 4.6 & 1.7 \\
\hline & NQ5 & 7.8 & 15.8 & 6.1 & 0.1 & 4864 & 99.0 & 6.4 & 2.3 \\
\hline & NQ6 & 13.7 & 10.9 & 9.6 & 0.4 & 3875 & 456.7 & 14.7 & 4.8 \\
\hline AVARAGE & & 18.3 & 38.0 & 21.4 & 0.9 & 7940.2 & 417.4 & 26.3 & 6.2 \\
\hline
\end{tabular}


Table 5. Permissible Levels of Heavy Metals ( $\mu \mathrm{g} g-1)$ for Marine Sediments Quality Guidelines according to Canadian, Ontario and Florida Guidelines[21;22;23] (Bennet and Cubbage, 1991; Persaud et al., 1990; MacDonald et al., 1996)

\begin{tabular}{|c|c|c|c|}
\hline \multirow{2}{*}{ Metals } & \multicolumn{3}{|c|}{ Levels of heavy metals $(\boldsymbol{\mu g}$ g-1) } \\
\cline { 2 - 4 } & TEL & PEL & SEL \\
\hline $\mathrm{Cd}$ & $0.6-0.7$ & 4.21 & 10 \\
\hline $\mathrm{Cu}$ & $16-18.7$ & 108 & 110 \\
\hline $\mathrm{Ni}$ & $15.9-16$ & 42.8 & 75 \\
\hline $\mathrm{Zn}$ & $120-124$ & 271 & 820 \\
\hline $\mathrm{Pb}$ & $30.2-46.7$ & 112 & 250 \\
\hline $\mathrm{Mn}$ & 460 & - & 1110 \\
\hline $\mathrm{Fe}$ & 20000 & - & 40000 \\
\hline
\end{tabular}

TEL: The Threshold Effect Level, PEL: The Probable Effect Level, SEL: The Severe Effect Level

\subsection{Natural Radionuclides}

The ${ }^{232} \mathrm{Th}$ concentration was determined from the average concentrations of ${ }^{212} \mathrm{~Pb}$ $(238.6 \mathrm{keV})$ and ${ }^{228} \mathrm{Ac}(911.1 \mathrm{keV})$ in the samples, and that of ${ }^{226} \mathrm{Ra}$ was determined from the average concentrations of ${ }^{214} \mathrm{~Pb}(351.9 \mathrm{keV})$ and ${ }^{214} \mathrm{Bi}(609.3,1120.3$ and $1764.5 \mathrm{keV})$ decay products. The ${ }^{40} \mathrm{~K}$ activity was determined by the peak at the energy $1460.8 \mathrm{keV}$ [24].

\subsubsection{Uncertainty of the Determination of Net Peak Areas}

The uncertainty of each single net-peak area is determined by the spectrum-evaluation code. It takes into account the Poisson uncertainties of the counts in the individual channels as well as the uncertainty of the background determination. Sometimes, a peak cannot be attributed unambiguously to a single nuclide. If it seems that the contributions of other nuclides to a peak are very small, no correction was applied. Due to this procedure, it is thought that a maximum inaccuracy of $2 \%$ was assumed due to contributions of other nuclides but it must be pointed out that in the average, this uncertainty should be smaller [25]. By repeated measurements, it could be verified that the total uncertainty of the efficiency calibration was $5 \%$.

Table 6. Activity Concentrations of the Radioelements (in Bq $\mathrm{kg}^{-1}$ ) Found in Studied Samples

\begin{tabular}{|c|c|c|c|c|}
\hline Samples Location & $\begin{array}{c}\text { Sample } \\
\text { Name }\end{array}$ & ${ }^{226} \mathrm{Ra} \mathrm{A}\left(\mathrm{Bq} \mathrm{kg}{ }^{-1}\right)$ & ${ }^{232} \mathrm{Th} \mathrm{A}\left(\mathrm{Bq} \mathrm{kg}{ }^{-1}\right)$ & ${ }^{40} \mathrm{KA}\left(\mathrm{Bq} \mathrm{kg}{ }^{-1}\right)$ \\
\hline south & SQ1 & $32.4 \pm 2.2$ & $25.9 \pm 2.7$ & $350 \pm 19.5$ \\
\hline \multirow[t]{5}{*}{ (El-Edua area) } & SQ2 & $18.8 \pm 1.7$ & $16.0 \pm 1.7$ & $103.5 \pm 5.8$ \\
\hline & SQ3 & $29.0 \pm 2.0$ & $26.0 \pm 2.6$ & $180.7 \pm 10.1$ \\
\hline & SQ4 & $37.5 \pm 2.6$ & $25.2 \pm 2.6$ & $262.6 \pm 14.7$ \\
\hline & SQ5 & $20.4 \pm 2.3$ & $20.5 \pm 2.3$ & $377.9 \pm 21.1$ \\
\hline & SQ6 & $17.2 \pm 2.2$ & $12.0 \pm 1.6$ & $274.5 \pm 15.3$ \\
\hline Middle & SQ7 & $18.7 \pm 1.4$ & $11.7 \pm 1.2$ & $88.6 \pm 5.1$ \\
\hline (Quseir Harbour) & Q1 & $16.6 \pm 1.3$ & $19.4 \pm 4.7$ & $393.6 \pm 22.7$ \\
\hline
\end{tabular}




$\begin{array}{ccccc} & \text { Q2 } & 27.4 \pm 1.8 & 18.9 \pm 1.9 & 341.8 \pm 19.2 \\ & \text { Q3 } & 33.9 \pm 2.2 & 22.3 \pm 4.3 & 324.9 \pm 18.4 \\ \text { Q4 } & 33.4 \pm 3.1 & 13.0 \pm 1.7 & 297.3 \pm 16.9 \\ & \text { Q5 } & 29.0 \pm 2.0 & 23.2 \pm 2.2 & 627.9 \pm 35.0 \\ & \text { Q6 } & 17.0 \pm 1.0 & 15.2 \pm 1.8 & 266.8 \pm 15.2 \\ \text { Q7 } & 26.7 \pm 2.2 & 16.5 \pm 1.8 & 114.6 \pm 6.5 \\ & \text { Q8 } & 28.1 \pm 1.9 & 24.6 \pm 2.8 & 212.0 \pm 12.2 \\ & \text { Q9 } & 17.2 \pm 1.0 & 12.9 \pm 1.8 & 101.0 \pm 6.1 \\ & \text { Q10 } & 57.8 \pm 5.0 & 33.0 \pm 3.2 & 101.1 \pm 5.6 \\ & \text { Q11 } & 5.2 \pm 0.4 & 3.9 \pm 1.0 & 14.8 \pm 1.1 \\ & \text { Q12 } & 34.7 \pm 4.0 & 47.2 \pm 10.8 & 612.7 \pm 35.7 \\ & \text { Q13 } & 13.3 \pm 0.8 & 13.9 \pm 1.5 & 447.1 \pm 24.9 \\ \text { north } & \text { Q14 } & 31.8 \pm 2.4 & 4.2 \pm 0.8 & 2665.4 \pm 149.4 \\ \text { (N. Flaminko Village) } & \text { Q15 } & 21.0 \pm 2.0 & 22.6 \pm 5.4 & 354.7 \pm 21.2 \\ & \text { NQ1 } & 27.6 \pm 2.1 & 34.7 \pm 5.7 & 152.9 \pm 8.53 \\ & \text { NQ2 } & 29.8 \pm 2.0 & 29.6 \pm 2.9 & 138.7 \pm 7.7 \\ & \text { NQ3 } & 51.5 \pm 6.0 & 33.8 \pm 4.5 & 88.8 \pm 5.0 \\ & \text { NQ4 } & 1.28 \pm 0.1 & 3.9 \pm 0.9 & 34.1 \pm 2.7 \\ & \text { NQ5 } & 29.4 \pm 2.2 & 19.2 \pm 1.9 & 126.0 \pm 7.0 \\ & \text { NQ6 } & 14.9 \pm 1.6 & 14.3 \pm 1.4 & 98.1 \pm 5.5 \\ & & 25.8 \pm 2.3 & 20.1 \pm 1.9 & 327 \pm 91.7\end{array}$

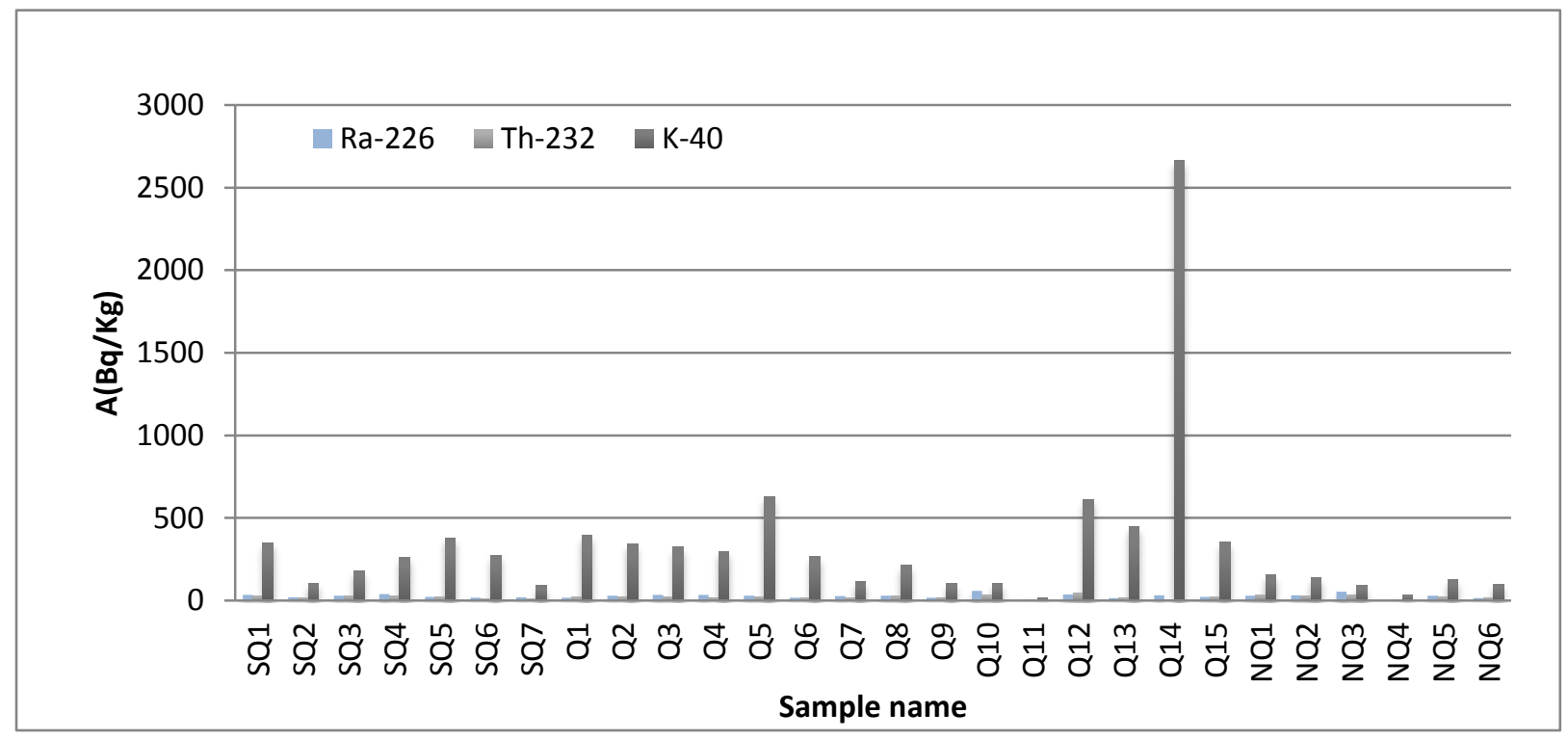

Figure 6. Activity Concentrations of the Radioelements (in $\mathrm{Bq} \mathrm{kg}{ }^{-1}$ ) Found in Studied Samples

Activity concentrations of ${ }^{226} \mathrm{Ra}\left({ }^{238} \mathrm{U}\right)$ series, ${ }^{232} \mathrm{Th}$ series and ${ }^{40} \mathrm{~K}$ (Bq.kg ${ }^{-1}$ dry weight) in the shore sediment samples are shown in Table 6 . The average activity \pm standard error (range) of ${ }^{226} \mathrm{Ra}\left({ }^{238} \mathrm{U}\right.$ ) series, ${ }^{232} \mathrm{Th}$ series and ${ }^{40} \mathrm{~K}$ were $25.8 \pm 2.3(1.3 \pm 57.8), 20.1 \pm 1.9$ (3.9 \pm 47.2) and $327 \pm 91.7$ (17.8-2665.4) Bq. $\mathrm{kg}^{-1}$ dry weight, respectively.

The average activities (range) of ${ }^{226} \mathrm{Ra}\left({ }^{238} \mathrm{U}\right.$ ) series, ${ }^{232} \mathrm{Th}$ series and ${ }^{40} \mathrm{~K}$ in Egyptian soil are 17 (5-64), 18 (2-96) and 320 (29-650) Bq. $\mathrm{kg}^{-1}$ dry weight, respectively (UNSCEAR, 2000). 
Also the World's average Activity concentrations $\left(\mathrm{Bq} \cdot \mathrm{kg}^{-1}\right)$ of ${ }^{226} \mathrm{Ra},{ }^{232} \mathrm{Th}$ and ${ }^{40} \mathrm{~K}$ measured worldwide were 35,30 and 400, respectively [26].

In our study the average concentrations values of ${ }^{226} \mathrm{Ra},{ }^{232} \mathrm{Th}$ and ${ }^{40} \mathrm{~K}$ are lower than that of world's average and higher than the average activities in Egyptian soil in ${ }^{226} \mathrm{Ra}$ $\left({ }^{238} \mathrm{U}\right)$ series.

The range of measured activities differed widely as their presence in marine environment depends on their physical, chemical and geo-chemical properties and the pertinent environment $\{1.2\}[27,28]$.

Figure 6 shows the results of Table 6 in graphical form, clearly indicating the high- and low-activity samples. Relationships between ${ }^{232} \mathrm{Th}$ and ${ }^{226} \mathrm{Ra},{ }^{40} \mathrm{~K}$ concentrations in the Red Sea shore sediment samples are given in Figures 8,9,10. The relationships between ${ }^{226} \mathrm{Ra}$ and ${ }^{232} \mathrm{Th}$ were medium correlated with correlation coefficients $(\mathrm{R})$ values of 0.451 . These medium correlations could be because $\mathrm{Ra}$ and The have some similarity in their environmental origin, i.e., the rocks from which the shore sediment were formed, and their chemical behaviour, The relationships between ${ }^{226} \mathrm{Ra},{ }^{40 \mathrm{~K}}$ and ${ }^{232} \mathrm{Th},{ }^{40} \mathrm{~K}$ were weak with correlation coefficient $(\mathrm{R})$ values of 0.0167 and 0.0332 , respectively .The weak correlation between radium and potassium could be explained due to the high potassium solubility.

The uranium concentration varied widely from 1.3 to $57.8 \mathrm{~Bq} / \mathrm{kg}$ dry weight. The main source of sediments to the beaches of the Egyptian Red Sea is the terrestrial deposits transported from the fringing mountains. The uranium concentration in the shore sediment depends on the uranium concentration in the fringing mountains (crystalline rocks), and the mobility of uranium from the rock and the shore sediment by rain and sea water, respectively $[29,30]$.

\subsection{Radiological Hazard Indices}

\subsubsection{Radium Equivalent $\left(\mathbf{R a}_{\mathrm{eq}}\right)$}

Radium equivalent $\left(\mathrm{Ra}_{\mathrm{eq}}\right)$ index in $\mathrm{Bq} / \mathrm{kg}$ is a widely used radiological hazard index. It is a convenient index to compare the specific activities of samples containing different concentrations of ${ }^{226} \mathrm{Ra},{ }^{232} \mathrm{Th}\left({ }^{228} \mathrm{Ra}\right)$ and ${ }^{40} \mathrm{~K}$. It was defined on the assumption that $10 \mathrm{~Bq} / \mathrm{kg}$ of ${ }^{226} \mathrm{Ra}, 7 \mathrm{~Bq} / \mathrm{kg}$ of ${ }^{232} \mathrm{Th}$ and $130 \mathrm{~Bq} / \mathrm{kg}$ of ${ }^{40} \mathrm{~K}$ produce the same gamma dose rate. It was calculated as follows [31].

$\mathrm{Ra}_{\mathrm{eq}}=\mathrm{C}_{\mathrm{Ra}}+1.43 \mathrm{C}_{\mathrm{Th}}+0.077 \mathrm{C}_{\mathrm{k}}$

Where $\mathrm{C}_{\mathrm{Ra}}, \mathrm{C}_{\mathrm{Th}}$ and $\mathrm{C}_{\mathrm{k}}$ are the activity concentrations of ${ }^{226} \mathrm{Ra},{ }^{232} \mathrm{Th}$ and ${ }^{40} \mathrm{~K}$ in $\mathrm{Bq} / \mathrm{kg}$, respectively. $\mathrm{Ra}_{\mathrm{eq}}$ was estimated for the collected samples and are given in Table 7. The values of $\mathrm{Ra}_{\mathrm{eq}}$ varied from 9.4 to $243.1 \mathrm{~Bq} \mathrm{~kg}^{-1}$ and the average value of $\mathrm{Ra}_{\mathrm{eq}}$ was found to be $78.7 \mathrm{~Bq} \mathrm{~kg}^{-1}$ The estimated highest value of $243.1 \mathrm{~Bq} \mathrm{~kg}^{-1}$ of $\mathrm{Ra}_{\mathrm{eq}}$ in the present work are lower than that of the recommended maximum value of $370 \mathrm{~Bq} \mathrm{~kg}^{-1}$ [42].

\subsubsection{Absorbed and Effective Dose Rate (Do)}

The absorbed dose rates due to gamma radiations in air(in outdoor air Do, $\mathrm{nGy} \mathrm{h}^{-1}$ )at $1 \mathrm{~m}$ above the ground surface for the uniform distribution of the naturally occurring radionuclides $\left({ }^{226} \mathrm{Ra},{ }^{232} \mathrm{Th}\right.$ and $\left.{ }^{40} \mathrm{~K}\right)$ were calculated based on guidelines provided by UNSCEAR (2000)[32]. The conversion factors used to compute absorbed gamma dose rate (Do) in air per unit activity concentration in $\mathrm{Bq} / \mathrm{kg}$ (dry weight) corresponds to $0.462 \mathrm{nGy} / \mathrm{h}$ for ${ }^{226} \mathrm{Ra}, 0.604 \mathrm{nGy} / \mathrm{h}$ for ${ }^{232} \mathrm{Th}$ and $0.042 \mathrm{nGy} \cdot \mathrm{h}^{-1}$ for ${ }^{40} \mathrm{~K}$. Therefore Do can be calculated as follows (UNSCEAR, 2000) [43]:

$\mathrm{D}_{\mathrm{o}}=0.462 \mathrm{C}_{\mathrm{Ra}}+0.604 \mathrm{C}_{\mathrm{Th}}+0.0417 \mathrm{C}_{\mathrm{K}}$ 
Where $\mathrm{C}_{\mathrm{Ra}}, \mathrm{C}_{\mathrm{Th}}$ and $\mathrm{C}_{\mathrm{k}}$ are the activity concentrations of ${ }^{226} \mathrm{Ra},{ }^{232 \mathrm{Th}}$ and ${ }^{40} \mathrm{~K}$ in $\mathrm{Bq} \cdot \mathrm{kg}^{-1}$, respectively. Table 7 gives the results for the absorbed dose rate in air for samples. The authors note that Quseir Harbour shows the highest values of $126.5 \mathrm{nGy} \mathrm{h}^{-1}$.

To estimate the annual effective dose rates doses, one has to take into account the conversion coefficient from absorbed dose in air to effective dose and the indoor occupancy factor. proposed by UNSCEAR, (2000) [43], a value of $0.7 \mathrm{~Sv} \mathrm{~Gy}^{-1}$ was used for the conversion coefficient from absorbed dose in air to effective dose received by adults, and 0.8 for the indoor occupancy factor, implying that $20 \%$ of time is spent outdoors, on average, around the world.

The annual effective dose rate outdoors in units of $(\mathrm{mSv} / \mathrm{y})$, is calculated by the following formula (SCEAR, 2000)

$\operatorname{AEDE}\left(\mathrm{m} \frac{\mathrm{Sv}}{\mathrm{y}}\right)=\mathrm{D}_{\mathrm{O}}(0.2 \times 365.25 \mathrm{~d} \times 24 \mathrm{~h}) \times\left(0.7 \times 10^{-3}\right)$

Whereas, $D_{0}$ is dose rate in $(n G y / h),(0.2 * 24 h * 365.25 d)$ is the outdoor occupancy time and $\left(0.7 * 10^{-3}\right)$ is the conversion coefficient in Sv.Gy ${ }^{-1}$ (Al-Trabulsy et al., 2011) [33]. The experimental results of the annual effective dose rate are presented in Table 7, From the results it is clear that the average total annual dose (based on the samples of this study) is $45.3 \mu \mathrm{Svy}^{-1}$. The International Commission on Radiological Protection (ICRP, 1993) has recommended the annual effective dose equivalent limit of $1 \mathrm{mSvy}^{-1}$ for the individual members of the public and $20 \mathrm{mSvy}^{-1}$ for the radiation workers [34].

\subsubsection{Calculation of nesHazard Indexes:}

\section{External Hazard Index $\left(\mathrm{H}_{\mathrm{ex}}\right)$}

The external hazard index $\left(\mathrm{H}_{\mathrm{ex}}\right)$ represents the external radiation exposure associated with gamma irradiation from radionuclides of concern. The value of $\mathrm{H}_{\mathrm{ex}}$ should not exceed the maximum acceptable value of one in order to keep the hazard insignificant. The external hazard index $\left(\mathrm{H}_{\mathrm{ex}}\right)$ is defined by equation [35]:

$$
\mathrm{H}_{\mathrm{ex}}=\left(\mathrm{C}_{\mathrm{u}} / 370+\mathrm{C}_{\mathrm{Th}} / 259+\mathrm{C}_{\mathrm{k}} / 4810\right) \leq 1
$$

Where $\mathrm{C}_{\mathrm{Ra}}, \mathrm{C}_{\mathrm{Th}}$ and $\mathrm{C}_{\mathrm{K}}$ are the concentration in $\left(\mathrm{Bq} \mathrm{Kg}^{-1}\right)$ of radium, thorium and potassium respectively.

\section{Internal Hazard Index $\left(\mathbf{H}_{\text {in }}\right)$}

The internal hazard index $\left(\mathrm{H}_{\mathrm{in}}\right)$ is used to control the internal exposure to ${ }^{222} \mathrm{Rn}$ and its radioactive progeny [44]. The internal exposure to radon and its daughter products is quantified by the internal hazard index $\left(\mathrm{H}_{\mathrm{in}}\right)$, which is given by the following equation (Krieger, 1981):

$$
\mathrm{H}_{\text {in }}=\left(\mathrm{C}_{\mathrm{Ra}} / 185+\mathrm{C}_{\mathrm{Th}} / 259+\mathrm{C}_{\mathrm{k}} / 4810\right)<1
$$

Where $\mathrm{C}_{\mathrm{Ra}}, \mathrm{C}_{\mathrm{Th}}$ and $\mathrm{C}_{\mathrm{K}}$ are the activity concentrations of ${ }^{226} \mathrm{Ra},{ }^{232} \mathrm{Th}$ and ${ }^{40} \mathrm{~K}$ in Bq.kg${ }^{1}$, respectively. The value of $\mathrm{H}_{\mathrm{in}}$ must be less than the unity to have negligible hazardous effects of radon and its short-lived progeny, the calculated values of these indices are given in Table 7. 


\section{Representative Level Index (I $\gamma \mathbf{r})$ :}

An additional hazard index so called representative level index is calculated by using the formula of Harb, [42]:

$$
I_{\gamma r}=\left(C_{u} / 300+C_{T h} / 200+C_{k} / 3000\right)
$$

Where $\mathrm{C}_{\mathrm{U}}, \mathrm{C}_{\mathrm{Th}}$ and $\mathrm{C}_{\mathrm{K}}$ are the specific activities $\left(\mathrm{Bq} \mathrm{kg}{ }^{-1}\right)$ of ${ }^{238} \mathrm{U},{ }^{232} \mathrm{Th}$ and ${ }^{40} \mathrm{~K}$, respectively. The value of these indexes must be less than unity in order to keep the radiation hazard insignificant.

\section{Excess Lifetime Cancer Risk (ELCR):}

Excess lifetime cancer risk (ELCR) was calculated using the following equation and presented in Table 7.

$\operatorname{ELCR}=\operatorname{AEDExDL}(70 \mathrm{y}) * \operatorname{Rf}\left(0.5 \mathrm{SV}^{-1}\right)$

where AEDE, DL and RF are the annual effective dose equivalent, duration of life (70 y) and risk factor $\left(\mathrm{Sv}^{-1}\right)$, fatal cancer risk per sievert. For stochastic effects, ICRP 60 uses values of 0.05 for the public [36]. The calculated value of ELCR showed that the highest value $\left(543.2 * 10^{-6}\right)$ was in Quseir Harbour. This value of ELCR was higher than the world average $0.29 \times 10^{-3}$ (UNSCEAR, 2000). For the soil sample in Quseir city, Egypt.

Table 7. Radium Equivalent $\left(\mathrm{Bq} \mathrm{kg}^{-1}\right)$, the Dose Rate $\left(\mathrm{nGy} \mathrm{h}{ }^{-1}\right)$, Hazard Indices (Hex and Hin) (nGy h $\left.{ }^{-1}\right)$, Annual Effective Dose Rate $\left(\mu \mathrm{Svy}^{-1}\right)$, Excess Lifetime Cancer Risk (ELCR) Gamma Index (Iy) and Annual Gonadal, Dose Equivalent (AGDE) $\left(\mu \mathrm{S} \vee \mathbf{y}^{-1}\right)$

\begin{tabular}{lllllllll}
\hline $\begin{array}{l}\text { Code } \\
\text { no. }\end{array}$ & Raeq & D. rate & Hex & Hin & A. Eff. & ELCR*10-6 & (IY) & AGDE \\
\hline SQ1 & 96.3 & 44.9 & 0.3 & 0.3 & 55.1 & 192.8 & 0.3 & 318.0 \\
SQ2 & 49.6 & 22.6 & 0.1 & 0.2 & 27.7 & 96.9 & 0.2 & 157.4 \\
SQ3 & 80.1 & 36.5 & 0.2 & 0.3 & 44.8 & 156.7 & 0.3 & 255.1 \\
SQ4 & 93.8 & 43.3 & 0.3 & 0.3 & 53.1 & 185.9 & 0.3 & 303.7 \\
SQ5 & 78.8 & 37.3 & 0.2 & 0.2 & 45.7 & 160.0 & 0.3 & 267.3 \\
SQ6 & 55.5 & 26.4 & 0.1 & 0.1 & 32.4 & 113.5 & 0.2 & 189.5 \\
SQ7 & 42.2 & 19.3 & 0.1 & 0.1 & 23.7 & 83.0 & 0.1 & 134.4 \\
Q1 & 74.7 & 35.5 & 0.2 & 0.2 & 43.6 & 152.5 & 0.3 & 256.1 \\
Q2 & 80.7 & 38.1 & 0.2 & 0.2 & 46.7 & 163.4 & 0.3 & 270.9 \\
Q3 & 90.9 & 42.5 & 0.2 & 0.3 & 52.1 & 182.4 & 0.3 & 300.3 \\
Q4 & 74.8 & 35.4 & 0.2 & 0.2 & 43.5 & 152.1 & 0.3 & 250.7 \\
Q5 & 110.6 & 53.2 & 0.3 & 0.2 & 65.2 & 228.2 & 0.4 & 383.9 \\
Q6 & 59.3 & 28.0 & 0.2 & 0.2 & 34.3 & 120.1 & 0.2 & 199.9 \\
Q7 & 59.1 & 27.0 & 0.2 & 0.2 & 33.1 & 115.9 & 0.2 & 187.5 \\
Q8 & 79.7 & 36.6 & 0.2 & 0.2 & 44.8 & 156.9 & 0.3 & 256.4 \\
Q9 & 43.4 & 19.9 & 0.1 & 0.1 & 24.4 & 85.3 & 0.1 & 138.7 \\
Q10 & 83.0 & 37.0 & 0.2 & 0.3 & 45.4 & 158.8 & 0.3 & 256.2 \\
Q11 & 12.2 & 5.5 & 0.03 & 0.04 & 6.8 & 23.7 & 0.0 & 38.2 \\
Q12 & 149.3 & 69.6 & 0.4 & 0.4 & 85.4 & 298.8 & 0.5 & 496.6
\end{tabular}




\begin{tabular}{lllllllll} 
Q13 & 67.6 & 32.9 & 0.2 & 0.1 & 40.3 & 141.1 & 0.2 & 239.6 \\
Q14 & 243.1 & 126.5 & 0.7 & 0.2 & 155.2 & 543.2 & 0.8 & 953.0 \\
Q15 & 80.7 & 37.9 & 0.2 & 0.2 & 46.5 & 162.8 & 0.3 & 270.9 \\
NQ1 & 89.0 & 40.0 & 0.2 & 0.3 & 49.1 & 171.7 & 0.3 & 278.5 \\
NQ2 & 82.8 & 37.3 & 0.2 & 0.3 & 45.8 & 160.2 & 0.3 & 259.3 \\
NQ3 & 106.6 & 47.8 & 0.3 & 0.4 & 58.7 & 205.3 & 0.4 & 328.2 \\
NQ4 & 9.4 & 4.3 & 0.03 & 0.02 & 5.3 & 18.6 & 0.03 & 30.8 \\
NQ5 & 66.5 & 30.3 & 0.2 & 0.2 & 37.2 & 130.2 & 0.2 & 210.6 \\
NQ6 & 42.9 & 19.5 & 0.1 & 0.1 & 24.0 & 83.9 & 0.1 & 136.6 \\
Average & 78.7 & 37.0 & 0.2 & 0.2 & 45.3 & 158.7 & 0.3 & 263.1 \\
Range & $9.4-243.1$ & $4.3-126.5$ & $0.04-0.7$ & $0.02-0.4$ & $5.3-155.2$ & $18.6-543.2$ & $0.03-0.8$ & $30.8-953$ \\
\hline
\end{tabular}

\section{Annual Gonadal Equivalent (AGDE):}

The annual gonadal dose equivalent (AGDE, $\mu \mathrm{Svy}^{-1}$ ) due to the specific activities of ${ }^{226} \mathrm{Ra},{ }^{232} \mathrm{Th}$ and ${ }^{40} \mathrm{~K}$ was calculated using the following formula [37]:

$$
\mathrm{AGDE}=3.09 \mathrm{C}_{\mathrm{Ra}}+4.18 \mathrm{C}_{\mathrm{Th}}+0.314 \mathrm{C}_{\mathrm{k}}\left(\mu \mathrm{Svy}^{-1}\right)
$$

The average values of AGDE are presented in Table 7. As can be seen, the highest values ware in Quseir Harbour.

Table 8. Comparison of Radionuclide Activities in $\mathrm{Bq} \mathrm{kg}^{-1}$ from Sediments of the Study Areas and other Coastal and Aquatic Environmental Locations

\begin{tabular}{clcccc}
\hline Country & \multicolumn{1}{c}{ Location } & ${ }^{226}$ Ra & ${ }^{232}$ Th & ${ }^{40} \mathbf{K}$ & References \\
\hline Egypt & El-Hamraween SS & $29 \pm 0.4$ & $8 \pm 0.1$ & $282 \pm 7$ & {$[38]$} \\
Egypt & El-Hamraween BS & $238 \pm 4$ & $11 \pm 0.3$ & $195 \pm 7$ & {$[49]$} \\
Egypt & Ras El Behar SS & $14 \pm 0.3$ & $13 \pm 0.3$ & $396 \pm 12$ & {$[49]$} \\
Egypt & Ras El Behar BS & $16 \pm 0.4$ & $19 \pm 0.4$ & $266 \pm 10$ & {$[49]$} \\
Egypt & Safaga sand & $25.3 \pm 13.7$ & $21.4 \pm 10$ & $618 \pm 122$ & {$[39]$} \\
Egypt & Hurgada sand & $20.6 \pm 9.6$ & $22.4 \pm 10$ & $548 \pm 82$ & {$[50]$} \\
Egypt & Red Sea shore sediment & $24.7 \pm 4.3$ & $31.4 \pm 9.6$ & $427.5 \pm 35$ & {$[5]$} \\
Sudan & Port Sudan & $11.05 \pm 2.2$ & ----- & $311 \pm 84$ & {$[40]$} \\
Sudan & Red Sea Coastal, Sudan & 11.6 & 6.02 & 158.4 & {$[41]$} \\
Jordon & Gulf Aqaba, Red Sea & $9.5 \pm 0.15$ & $10 \pm 0.14$ & $734 \pm 19$ & {$[42]$} \\
Egypt & Nasser lake & $14.4-22$ & $18.4-24.4$ & $222-326$ & {$[43]$} \\
Egypt & Suez canal & $4.9-20.2$ & $3.3-35.4$ & $59-368$ & {$[44]$} \\
Egypt & River Nile sediments & $(3.8-34.9)$ & $(2.9-30.1)$ & $(112-313)$ & {$[45]$} \\
Egypt & Brullus lake & $14(10-22)$ & $20(12-34)$ & $312(268-401)$ & {$[46]$} \\
Egypt & Red SeaWadies & $27(18-48)$ & $38(34-110)$ & $419(214-641)$ & {$[47]$} \\
Egypt & Quseir harbour & $71(34-81)$ & $83(31-98)$ & $513(336-611)$ & {$[48]$} \\
Egypt & Safaga harbour & $66(51-76)$ & $71(17-141)$ & $493(272-866)$ & {$[59]$} \\
Egypt & El-Esh area & $92(47-142)$ & $162(272-866)$ & $681(143-1252$ & {$[59]$}
\end{tabular}




$\begin{array}{llcccc}\text { Egypt } & \text { El-Edua area } & 25(17-38) & 20(12-26) & 234(89-378) & \text { Present work } \\ \text { Egypt } & \text { Quseir Harbour } & 26(5-58) & 19(4-47) & 459(18-2665) & \text { Present work } \\ \text { Egypt } & \text { north Flaminko Village } & 26(1.3-52) & 23(4-35) & 106(34-153) & \text { Present work }\end{array}$

\section{Conclusions}

The study area is very rich with natural resources in the land or in the Sea and its preservation is a national interest. Most of the investigated areas are covered by sand blanked. Gravel sized and carbonate dominated in the intertidal sediments. The highest content of organic matter in the studied sediments of the study areas is mainly due to human activities either in the Sea or long the coast. The carbonate content in South Quseir (El-Edua area) samples is low, indicating the oversupply of terrigenous materials, while Quseir Harbour and north Quseir (Flaminko Village area) samples recorded a relatively high average carbonate content due to phosphate shipment and the abundance of coral reefs. In some areas, the seagrass cover in the tidal flat zone is the main reason for high organic matter content in the studied localities especially in Quseir Harbour.

Generally, the behavior of heavy metals in the marine sediments at the study areas is complex, and the human impact on Quseir area is clearly reflected by their concentrations. In comparison with the concentrations of metals in sediments of the study areas along the Egyptian Red Sea with the other studies, the Egyptian Red Sea coast is relatively uncontaminated.

The average activities of ${ }^{226} \mathrm{Ra},{ }^{232} \mathrm{Th}$ and ${ }^{40} \mathrm{~K}$ in Quseir Harbour are higher than those in north and south Quseir due to local contamination by phosphate shipment. Furthermore, the higher radionuclide activity in Quseir Harbour is due to the increase of fine particles from land filling and dredging to prepare the Port Shipping. The average activities range of ${ }^{226} \mathrm{Ra},{ }^{232} \mathrm{Th}$ and ${ }^{40} \mathrm{~K}$ in the studied areas is almost near those in other coastal and aquatic environments in the Red Sea.The range of measured activities differs widely as their presence in marine environment depends on their physical, chemical and geochemical properties and the pertinent environment. According to The average activities of ${ }^{226} \mathrm{Ra}\left({ }^{238} \mathrm{U}\right)$ series, ${ }^{232} \mathrm{Th}$ series and ${ }^{40} \mathrm{~K}$ in Egyptian soil the Quseir coast along Red Sea is relatively contaminated.

The southern Red Sea sector is undergoing rapid development for tourism and mining. Management of coastal area at Quseir district is an example can be applied an the southern Red Sea sector coastal areas. 


\section{Appendixes}

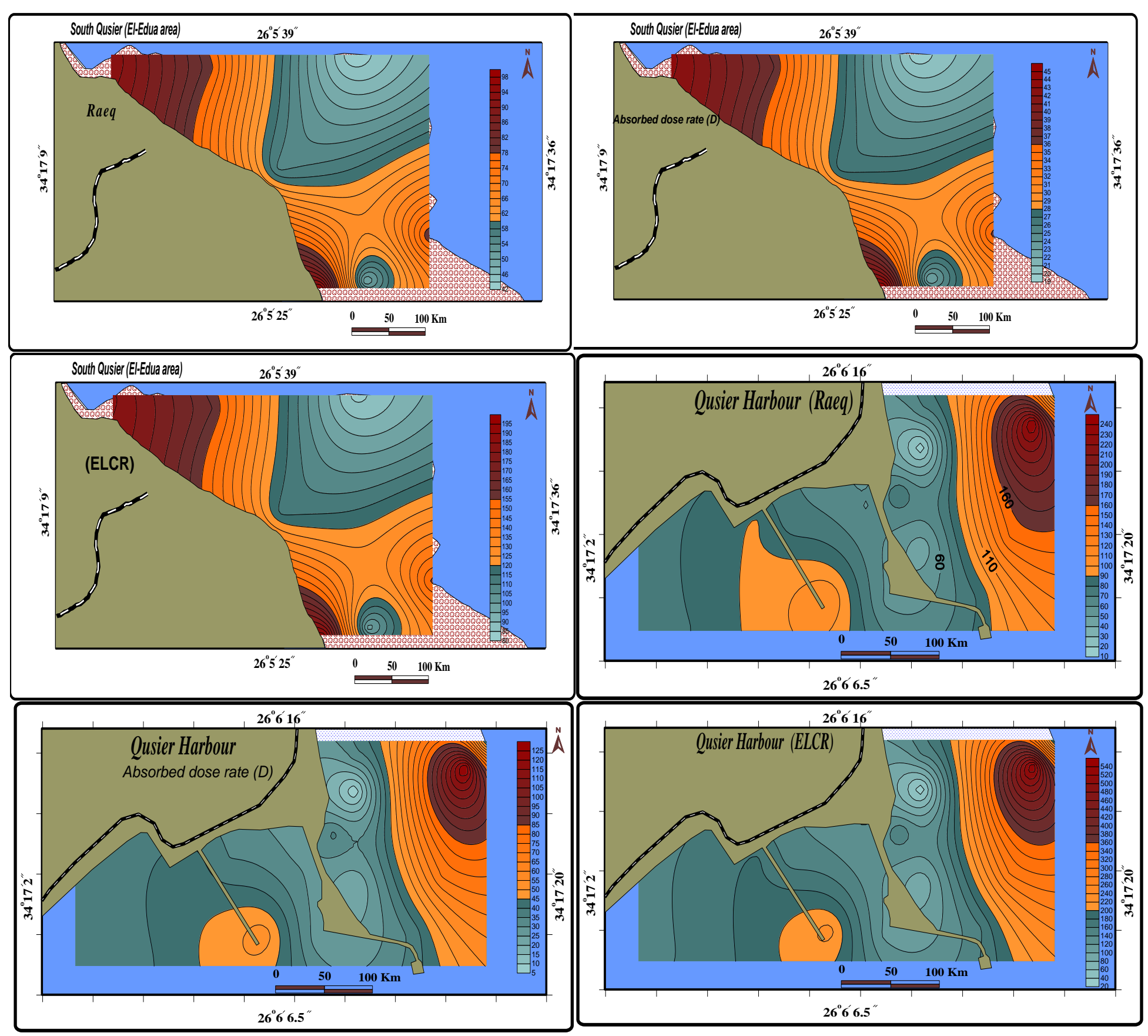



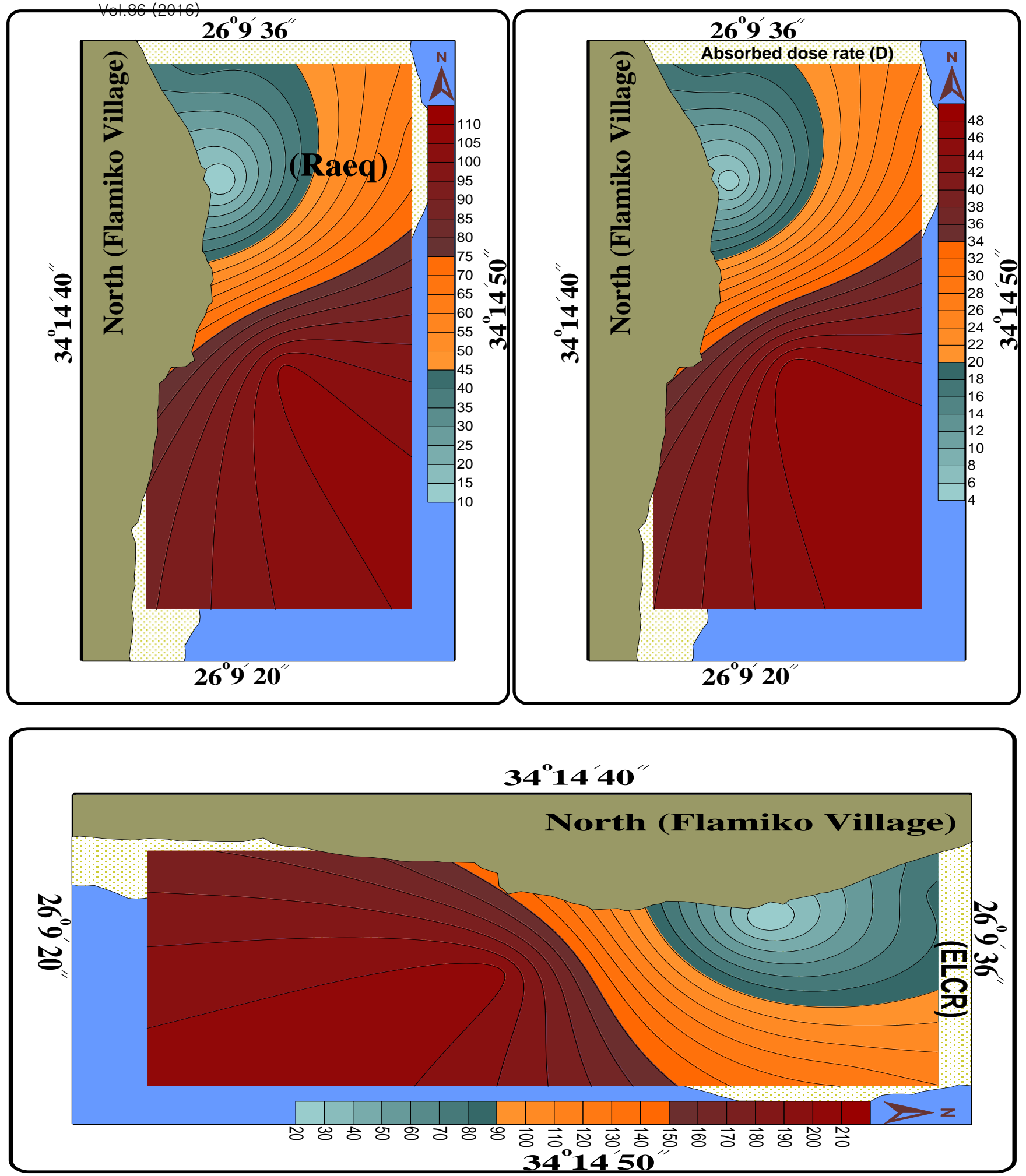

Figure 7. The Activity Patterns Distributions of the Different Radiological Hazard Parameters at Quseir City Coastal

\section{References}

[1] H. A. Madkour, "Geochemical and environmental studies of recent marine sediments and some invertebrates of the Red Sea”, Egypt. Ph.D. Thesis, South Vally Univ., Qena, (2004), pp. 317.

[2] S. U. El-Kameesy, S. Abd EL-Ghany, S. M. El-Minyawi, Z. Miligy and E. M. El-Mabrouk, "Natural radioactivity of beach sand samples in the Tripoli Region", Northwest Libya. Turk. Journal of Eng. Environ. Sci., vol. 32, (2008), pp. 245-251. 
[3] M. Azouazi, Y. Ouahidi, S. Fakhi, Y. Andres, J. Ch. Abbe and M. Benmansour, "Natural radioactivity in phosphates, phosphogypsum and natural waters in Morocco", Journal of Environ. Radioact., vol. 54, (2001), pp. 231-242.

[4] M. Baskaran and P. H. Santschi, "The role of particles and colloids in the transport of radionuclides in coastal environments of Texas", Mar. Chem., vol. 43, (1993), pp. 95-114.

[5] J. A. Sanchez-Cabeza, M. Ortega, J. Merino and P. Masque, "Long-term box modelling of 137Cs in the Mediterranean Sea. J. Mar. Syst., vol. 33-34, (2002), pp. 457-472.

[6] H. E. Heldal, P. Varskog and L. FØyn, "Distribution of selected anthropogenic radionuclides (137Cs, $238 \mathrm{Pu}, 239,240 \mathrm{Pu}$ and $214 \mathrm{Am})$ in marine sediments with emphasis on the Spitsbergen Bear Island area", Sci. Total Environ., vol. 293, (2002), pp. 233-245.

[7] N. A. Ahmed and H. A. Madkour, "The environmental impacts of the Red Sea coast at Quseir District, Red Sea, Egypt", The 3rd. Int. Conf. for Develop. and the Env. in the Arab World, (2006) March 21-23, pp. 733-757.

[8] American Society for Testing Materials (ASTM).Standard method for sampling surface soils for radionuclides. Report No. C (Philadelphia, PA: ASTM), (1983), pp. 983-998.

[9] American Society for Testing Materials (ASTM). Recommended practice for investigation and sampling soil and rock for engineering purposes. Report No. D (Philadelphia, PA: ASTM) Ann. Book of ASTM Standards (04.08) 420, (1986), pp. 109-113.

[10] E. W. Dean Jr., "Determination of carbonate and organic matter in calcareous sediments and sedimentary rocks by loss in ignition: comparison with other methods", Journal of Sediment Petrol, vol. 44, (1974), pp. 242-248.

[11] S. M. Flannery, D. R. Snodgrass and J. T. Whitmore, "Deepwater sediments and tropic conditions in Florida lakes", Hydrobiologia, vol. 92, (1982), pp. 597-602.

[12] M. Brenner and M. W. Binford, "Relationships between concentrations of sedimentary variables and tropic state in Florida lakes", Can J Fish Aquat Sci., vol. 45, (1988), pp. 294-300.

[13] R. Chester, F. G. Lin and A. S. Basaham, "Trace metals solid state speciation changes associated with the down-column fluxes of oceanic particulates", Geol. Soc. London, vol. 151, (1994), pp. 351-360.

[14] A. M. Mansour, "Sedimentary facies and carbonate-siliciclastic transition of Sharm El Bahari and Sharm El Qibli”, Red Sea, Egypt. Egypt. Jour. Geol., vol. 39-1, (1995), pp. 57-76.

[15] W. R. Maiklem, "Some hydraulic properties of bioclastic carbonate grains", Sedimentology, vol. 10, (1968), pp. 101-109.

[16] C. J. R. Braithwaite, "Setting behavior related to sieve analysis of skeletal sands", Sedimentology, vol. 20, (1973), pp. 51-262.

[17] A. M. Mansour, A. H. Nawar and A. M. Mohamed, "Recent intertidal sediments and negative impact of human activities", Red Sea coast, Egypt. Egyptian Jour. of Geo., vol. 41, no. 2A, (1997), pp. 239-272.

[18] A. M. Mansour, "Changes of sediment nature by environmental impacts of Sharm Abu Makkdeg area", Red Sea, Egypt. Sedimentology of Egypt, vol. 7, (1999), pp. 25-36.

[19] P. G. Jeffery, "Chemical methods of rock analysis", 2nd ed., pergamon press, Oxford, (1975), pp. 525.

[20] H. A. Madkour, "Geochemical and environmental studies of recent marine sediments and some hard corals of Wadi El-Gemal area of the Red Sea", Egypt. Egyptian Journal of Aquatic Research, vol. 31, no. 1, (2005), pp. 69-91.

[21] J. B. Bennet and J. Cubbage, "Summary of Criteria and Guidelines for Contaminated Freshwater Sediments", Washington State Department of Ecology, Olympia, WA, (1991).

[22] D. Persaud, R. Jaagumagi and A. Hayton, "The provincial sediment quality guidelines", Ontario Ministry of the Environment, (1990).

[23] D. D. MacDonald, R. S. Carr, F. D. Calder, E. R. Long and C. G. Ingersoll, "Development and evaluation of sediment qualityguidelines for Florida coastal waters", Ecotoxicology, vol. 5, (1996), pp. 253-278.

[24] D. M. Hamby and A. K. Tynybekov, "Uranium, thorium and potassium in soils along the shore of lake Issyk-Kyol in the Kyrghyz Republic", Environ. Monit. Assess., vol. 73, (2002), pp. 101-108.

[25] K. N. Yu, Z. J. Guan, M. J. Stoks and E. Young, "The assessment radiation of natural radiation dose commited to the Hong Kong people”, Journal of Environ. Radioact., vol. 17, no. 931, (1992).

[26] United Nations Scientific Committee on effects of Atomic Radiation. Exposures from natural radiation sources. UNSCEAR Report. United Nations, (2000).

[27] S. A. Khatir, M. O. Ahamed Mustafa, F. A. El-Khaangi, Y. O. Nigumi and E. Holm, "Radioactivity levels in the Red Sea coastal environment of Sudan", Marine Pollution Bulletin, vol. 36, no. 1, (1998a), pp. 19-26.

[28] S. A. Khatir, A. A. El-Ganawi, M. O. Ahamed and F. A. El-Khaangi, "Distribution of some natural and anthropogenic radionuclides in Sudanese harbour sediments", Journal of Radioanalytical and Nuclear chemistry, vol. 237, no. 1-2, (1998b), pp. 103-107.

[29] A. Strezov, M. Yordanov, M. Pimpl and T. Stoilova, "Natural radionuclides and plutonium content in Black Sea bottom sediments", Journal of Health Physics, vol. 70, no. 1, (1996), pp. 70-80.

[30] M. H. El Mamoney and A. E. Rifaat, "Discrimination of sources of barium in beach sediments", Marsa Alam to Shuqeir, Red Sea, Egypt, Journal King Abdulaziz Univ. Marine Sciences, vol. 12, (2001), pp. 149-160. 
[31] J. Beretka and P. J. Mathew, "Natural radioactivity of Australian building materials, industrial wastes and by-products", Health Physics, vol. 48, (1985), pp. 87-95.

[32] UNSCEAR: Sources and Effects of Ionizing Radiation. Report to general assembly. With scientific annexes. United Nations sales publications No. E.00.IX.3 Volume I: Sources and No. E.00.IX.4 (Volume II: Effects). United Nations, New York, (2000), pp. 1220.

[33] H. A. Al-Trabulsy, A. E. Khater and F. I. Habbani, "Radioactivity levels and radiological hazard indices at the Saudi coastline of the Gulf of Aqaba", Radiation Physics and Chemistry, vol. 80, (2011), pp. 343348.

[34] International Commission on Radiological Protection (ICRP). ICRP Publication 65. Ann. ICRP, Pergamon Press, vol. 23, no. 2, (1993).

[35] M. Jankovic, D. Todorovic and M. Savanovic, "Radioactivity measurements in soil samples collected in the Republic of Srpska", Radiation Measurements, vol. 43, (2008), pp. 1448-1452.

[36] V. Ramasamy, G. Suresh, V. Meenakshisundaram and V. Ponnusamy, "Horizontal and vertical characterization of radionuclides and minerals in river sediments”, Appl. Radiat. Isot., vol. 69, (2011), pp. 184-195.

[37] K. Mamont-Ciesla, B. Gwiazdowski, M. Biernacka and A. Zak, "Radioactivity of building materials in Poland", Vohra, G., Pillai, K. C. and Sadavisan, S., Eds. Natural Radiation Environment. Halsted Press, (1982), pp. 551.

[38] K. Salahel Din and P. Vesterbacka, "Radioactivity levels in some sediment samples from Red Sea and Baltic Sea”, Radiat Prot Dosim., vol. 148, (2011), pp. 101-106.

[39] A. M. El Arabi, "Natural radioactivity in sand used in thermal radiotherapy at the Red Sea coast", Journal of Environ Radioact., vol. 101, (2005), pp. 165-169.

[40] A. S. Khatir, A. A. El-Ganawi, M. M. O. Ahmed and F. A. El-Khangi, "Distribution of some natural and anthropogenic radionuclides in Sudanese harbour sediments", Journal of Radioanal Nucl Chem., vol. 237, (1998), pp. 103-107.

[41] A. S. Khatir, M. M. O. Ahmed, F. A. El-Khangi, Y. O. El-Nigumi and E. Holm, "Radioactivity levels in the Red Sea coastal environment of Sudan", Mar Pollut Bull., vol. 36, (1998), pp. 19-26.

[42] Z. Q. Ababneh, H. El-Omari, M. Rasheed, T. El-Najjar and A. Ababneh, "Assessment of gamma emitting radionuclides in sediment cores from the Gulf of Aqaba", Red Sea. Radiat Prot Dosim., vol. 141, (2010), pp. 289-298.

[43] A. E. Khater, Y. Y. Ebaid and S. A. El-Mongy, "Distribution pattern of natural radionuclides in Lake Nasser bottom sediments", Int. Congr. Ser., vol. 1276, (2005), pp. 405-406.

[44] M. S. El-Tahawy, M. A. Farouk, N. M. Ibrahiem and S. El-Mongey, "Natural and artificial radionuclides in the Suez Canal bottom sediments and stream water", Radiat Phys Chem., vol. 44, (1994), pp. 87-89.

[45] A. El-Gamal, S. Nasr and A. El-Taher, "Study of the spatial distribution of natural radioactivity in the upper Egypt Nile river sediments", Radiat Meas., vol. 42, (2007), pp. 457-465.

[46] H. El-Reefy, T. Sharshar, T. El-Nimr and H. Badran, "Distribution of gamma-ray emitting radionuclides in the marine environment of the Burullus Lake: II", Bottom sediments. Environ Monit Assess., vol. 169, (2010), pp. 273-284.

[47] A. El-Taher and H. A. Madkour, "Distribution and environmental impacts of metals and natural radionuclides in marinesediments in-front of different wadies mouth along the Egyptian Red Sea coast, Appl Radiat Isot., vol. 69, (2011), pp. 550-558.

[48] A. El-Taher and H. A. Madkour, "Environmental and radio-ecological studies on shallow marine sediments from harbour areas along the Red Sea coast of Egypt for identification of anthropogenic impactsIsotopes in Environmental and Health Studies", DOI:10.1080/10256016.2013.826211, (2013). 